Utah State University

DigitalCommons@USU

\title{
Perceptions of Agriculture Teachers Toward Including Students
} with Disabilities

\author{
Monica D. Giffing \\ Utah State University
}

Follow this and additional works at: https://digitalcommons.usu.edu/etd

Part of the Agricultural and Resource Economics Commons, and the Special Education and Teaching Commons

\section{Recommended Citation}

Giffing, Monica D., "Perceptions of Agriculture Teachers Toward Including Students with Disabilities" (2009). All Graduate Theses and Dissertations. 302.

https://digitalcommons.usu.edu/etd/302

This Thesis is brought to you for free and open access by the Graduate Studies at DigitalCommons@USU. It has been accepted for inclusion in All Graduate Theses and Dissertations by an authorized administrator of DigitalCommons@USU. For more information, please contact digitalcommons@usu.edu.

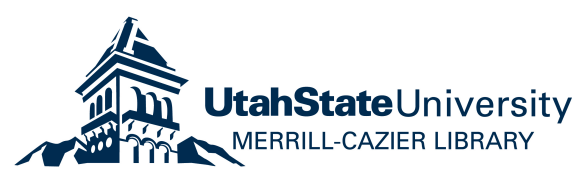




\title{
PERCEPTIONS OF AGRICULTURE TEACHERS TOWARD INCLUDING STUDENTS WITH DISABILITIES
}

\author{
by
}

Monica D. Giffing

A thesis submitted in partial fulfillment

of the requirements for the degree

of

MASTER OF SCIENCE

in

Agricultural Systems Technology

(Secondary and Postsecondary Agricultural Education)

Approved:

Brian K. Warnick, Ph. D.

Julie P. Wheeler, M. S.

Major Professor

Committee Member

Rudy S. Tarpley, Ph. D.

Byron Burnham, Ed. D.

Committee Member

Dean of Graduate Studies

UTAH STATE UNIVERSITY

Logan, Utah 
Copyright (C) Monica D. Giffing

All Rights Reserved 
ABSTRACT

The Perceptions of Agriculture Teachers on Including Students with Disabilities

by

\section{Monica D. Giffing, Master of Science}

Utah State University, 2009

Major Professor: Brian K. Warnick, Ph. D.

Department: Agricultural Systems Technology and Education

The inclusion of students with special needs in regular education classrooms has been required by federal law for more than three decades. However, much of the responsibility for successful accommodation of students with disabilities rests upon the shoulders of teachers. Previous research has indicated that successful inclusion of students with special needs is strongly influenced by the attitude of teachers involved. In this study, all secondary agriculture teachers in Utah were surveyed to determine their attitudes and perceptions related to their willingness and ability to include students with special needs in their classrooms and laboratories. Selected personal and professional characteristics were correlated with these attitudes and perceptions. A large majority of teachers responded that they understand the concept of inclusion, are in favor of including students with disabilities, and have had a positive experience teaching students with special needs. However, fewer respondents indicated that they had the skill level to 
successfully include students with disabilities. Overall, while teachers indicated

willingness to include the students with most of the specific types of disabilities, they were less positive in their perceived abilities to successfully accommodate students with some specific categories of special needs. 


\section{ACKNOWLEDGMENTS}

With sincerity I want to thank those who have helped make this accomplishment possible, Dr. Brian Warnick for his never-ending encouragement and for continuing to raise the bar, Dr. Rudy Tarpley for tolerating my moments of insanity, Julie Wheeler for helping me see the humor in everything, and the entire Utah State University ASTE Department for making me feel so welcome during this process. Special thanks to Dr. Natalie Williams, my sister, for showing me the importance of inclusion and the impact that it can have on teachers' and students' lives and for her support and feedback during this process. I also want to express my deepest gratitude to my family, Rob, Casey, and Jaynee, who have sacrificed beyond measure and tolerated many long days, and to my entire family for their support and especially my parents who never forget to say they are proud of my accomplishments. None of this would be possible without the loving guidance and gracious talents bestowed upon me by my Heavenly Father.

Monica D. Giffing 
CONTENTS

Page

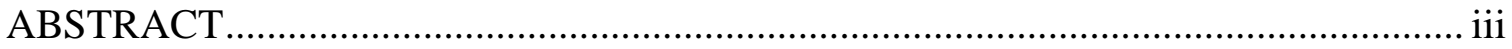

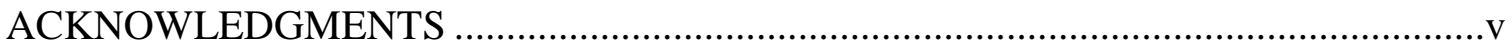

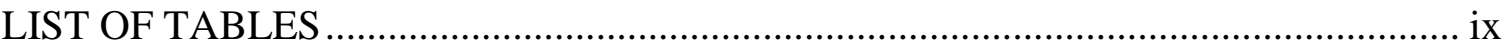

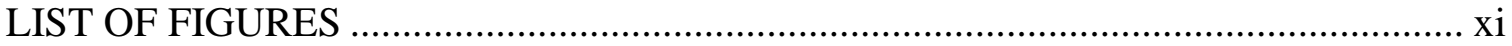

\section{CHAPTER}

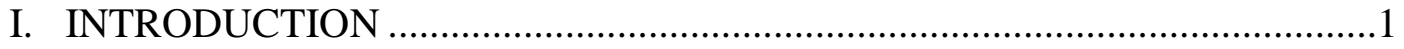

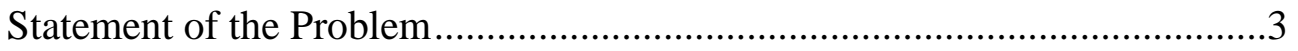

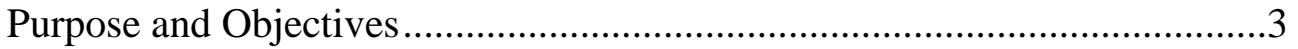

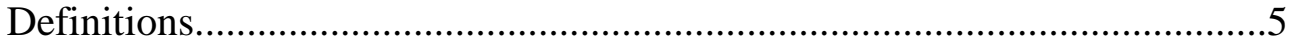

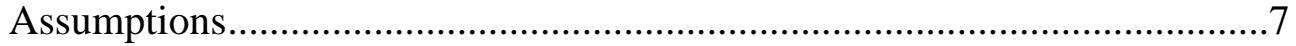

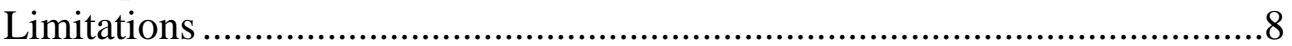

Significance of the Study ...............................................................

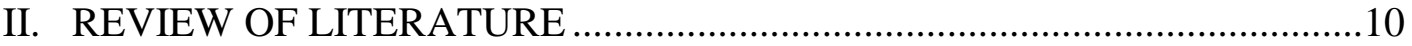

Theoretical Framework ........................................................................10

Attitudes toward Inclusion ........................................................................11

Perceptions of Skills and Abilities of

Including Students with Disabilities .................................................14

Agricultural Education for Students with Disabilities ...............................16

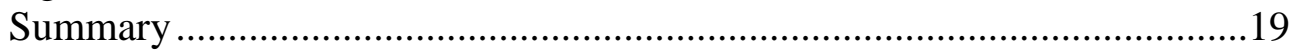

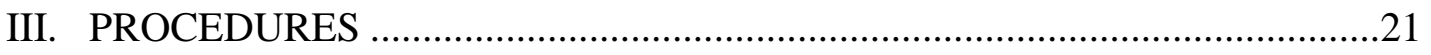

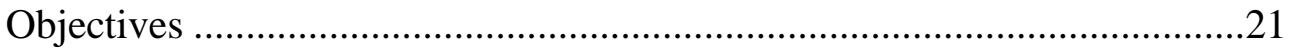

Instrumentation ..............................................................................22

Selection of Population ..........................................................................23

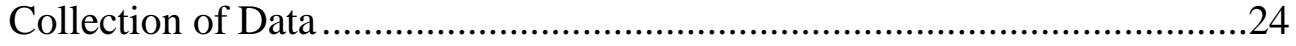

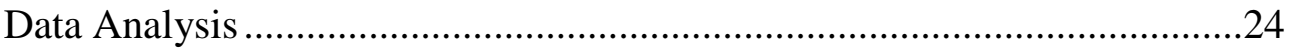


Objective One: Describe the Demographic Profile of Utah Secondary Agriculture Teachers.

Objective Two: Determine the Perceived Attitudes and Ability of Utah Agriculture Teachers Concerning the Inclusion of Students with Disabilities

Objective Three: Determine the Perceived Security Level of Utah Agriculture Teachers Concerning the Inclusion of Students with Disabilities

Objective Four: Determine the Willingness of Utah Agriculture

Teachers to Include Students with Specific Disabilities.

Objective Five: Determine the Skill Set of Utah Agriculture Teachers to include Students with Specific Disabilities

Objective Six: Determine the Satisfaction Level of Utah Agriculture Teachers with Available Support Services

Objective Seven: Determine the Willingness of Utah Agriculture Teachers to Participate in Professional Development Regarding Inclusion Activities

Objective Eight: Describe How Students with Special Needs are Included in the Utah Agriculture Teachers' Classroom/Laboratory........39

Objective Nine: Summarize the Education/Professional Development Utah Agriculture Teachers have Received Regarding Inclusion.

Objective Ten: List the Support Services Available to the Utah Agriculture Teachers

Objective Eleven: Correlate Selected Demographics Variables with the Analyzed Perceptions of Utah Agriculture Teachers on Inclusion of Students with Disabilities

V. CONCLUSIONS AND RECOMMENDATIONS

Summary

Purpose and Objectives.

Conclusions and Discussion

Recommendations and Implications

Recommendations for Further Study

Final Statement 
Appendix A: The Perceptions of Agriculture Teachers

on including Students with Disabilities ...............................................74

Appendix B: Pre-Notice Letter .................................................................86

Appendix C: Cover Letter and Informed Consent Document ......................88

Appendix D: First Reminder Post Card Mailing .........................................90

Appendix E: Final Reminder Letter..........................................................92

Appendix F: Responses to Open Ended Questions......................................94 


\section{LIST OF TABLES}

Table

1 Special Education Service Providers Utilized by Agricultural Teachers ...................29

2 Skill Level and Understanding of Including Students with Disabilities ....................30

3 Security Regarding Ability Concerning the Inclusion of Students with Disabilities

4 Teachers’ Willingness to Include Students with Disabilities

5 Teachers Perceived Skill Set When Including Students with Specific

Disabilities.....

6 Satisfaction and Needs for Support Services

7 Teachers’ Willingness to Participate in Professional Development .38

8 How Students with Special Needs Are Treated in the Classroom/Laboratory ..........40

9 Summary of Education and/or Professional Development Regarding Inclusion.......41

10 Support Services Available to Utah Agriculture Teachers .....................................42

11 Stepwise Multiple Regression Results of Gender with Survey Items.......................44

12 Stepwise Multiple Regression Results of Age with Survey Items ...........................45

13 Stepwise Multiple Regression Results of Community Size with Survey Items.........47

14 Stepwise Multiple Regression Results of Level of Education with Survey Items

15 Stepwise Multiple Regression Results of IEP Participation Items...........................51

16 Stepwise Multiple Regression Results of Years of Teaching Experience .................52

17 Stepwise Multiple Regression Results of Years of Experience Teaching Students with Disabilities 
18 Stepwise Multiple Regression Results of Number of Professional Development Workshops Attended..............................................................................58 


\section{LIST OF FIGURES}

Figure

Page

1. The influence of beliefs, perceptions, and attitudes toward

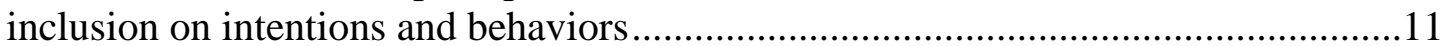




\section{CHAPTER 1}

\section{INTRODUCTION}

The desire to include students with disabilities in the classroom is sometimes shaded by the teacher's lack of knowledge, ability, and self efficacy (Center \& Ward, 1987). The concept of inclusion is that students with disabilities attend schools and participate in classes with typical students. In 1975, Congress passed The Education of

All Handicapped Children Act (Public Law 94-142), now codified as the Individuals with Disabilities Education Act (IDEA, Public Law 101-476, 1990). IDEA is a law ensuring services to children with disabilities throughout the nation. This law governs how states and public agencies provide early intervention, special education, and related services to more than 6.5 million eligible infants, toddlers, children and youth with disabilities. One application involves placement of students with disabilities into educational programs for and with typically developing students. This concept is also known as inclusion, and research has suggested it is vital from the beginning stages of a child's education (Gemmell-Crosby \& Hanzlik, 1994). IDEA requires that students be educated in the least restrictive environment regardless of any disability. Since the passing of IDEA, educators as a whole have had to adjust not only their perception of students with disabilities but their day to day classroom management procedures. Taking students with disabilities from special education classrooms and including them in general education classrooms requires adaptation on the part of the teachers and staff and may involve a reform of special education services (Gent \& Mulhauser, 1988; Stainback, Stainback, \& Forest, 1989). There has been an increase in momentum of inclusive education in recent years. A 
key factor in the successful implementation of the policy is the attitude of the teachers who carry the majority of the responsibility of implementing inclusion (Avramidis \& Norwich, 2002).

Hudson, Graham, and Warner (1979) stated:

If the mainstreaming effort is to be successful, it is crucial that the combined thoughts and energies of special and regular educators do not counteract each other or work at cross purposes. This, in turn, requires cooperation, properly trained personnel, careful planning and appropriate attitudes. (pp. 58-59)

They continued by stating that effective education for students with disabilities cannot be obtained without first understanding the regular educators' needs and outlook toward integration (Hudson et al.).

Werts, Wolery, Snyder, and Caldwell (1996) said, “It is imperative to ascertain teachers' perceptions of the factors that are critical to inclusive schooling and to identify the conditions that are seen as barriers” (pp. 9-10). Center and Ward (1987) acknowledged that “teachers' attitudes may be significantly modified by their pre-service training and the nature of their subsequent professional experience” (p. 41).

Dormody, Seevers, Andreasen, and VanLeeuwen (2006) found that agriculture teachers who had taken more formal courses on including students with disabilities felt more prepared to include students with disabilities in their classroom/laboratories. Research on mainstreaming denotes that teachers with appropriate training are more successful at adapting instructional practices and at meeting the needs of their students (Slavin, Leavey, \& Madden, 1984). 
Statement of the Problem

It has been noted that the obstacle of teachers’ attitudes is by far the most detrimental component for students with special needs (Pivik, McComas, \& Laflamme, 2002). Therefore, one of the most valuable elements to the inclusion process for a student is a positive attitude of the student's teachers (Guralnick, 1982; Hanline, 1985; Hudson et al., 1979; Odom \& McEvoy, 1990; Shotel, Iano, \& McGettingan, 1972; Williams \& Algozinne, 1979). Utah agriculture teachers’ attitudes toward the inclusion of students with disabilities and their perceived ability has never been specifically assessed. In order to provide students with fair education and the least restrictive educational environment, the profession needs to be aware of the teachers' attitudes, abilities, and needs. Once these attitudes and perceived abilities are clearly understood, appropriate professional development opportunities and necessary tools can be provided to the teachers.

\section{Purpose and Objectives}

The purpose of this study was to assess Utah agricultural education teachers’ attitudes toward including students with disabilities in their classrooms and laboratories and to determine their perceived ability to include students with disabilities in their classrooms and laboratories. The results of this study will help teacher educators and state leaders provide effective professional development opportunities based on current perceptions, abilities and needs of including students with disabilities in agricultural classrooms and laboratories.

To achieve this purpose, the following objectives served as guidelines: 
1. Describe the demographic profile of Utah secondary agriculture teachers;

2. Determine the perceived attitudes and ability of Utah agriculture teachers concerning the inclusion of students with disabilities;

3. Determine the perceived security level of Utah agriculture teachers concerning the inclusion of students with disabilities;

4. Determine the willingness of Utah agriculture teachers to include students with specific disabilities;

5. Determine the skill set of Utah agriculture teachers to include students with specific disabilities;

6. Determine the satisfaction level of Utah agriculture teachers with available support services;

7. Determine the willingness of Utah agriculture teachers to participate in professional development regarding inclusion activities;

8. Describe how students with special needs are included in the Utah agriculture teachers’ classroom/laboratories;

9. Summarize the education/professional development Utah agriculture teachers have received regarding inclusion;

10. List the support services available to the Utah agriculture teachers; and

11. Correlate selected demographic variables with the analyzed perceptions of Utah agriculture teacher on inclusion of students with disabilities. 


\section{Definitions}

Terms used in this report are specific to Special Education, and are those generally used by educators in Utah specific to disabilities (Utah State Office of Education, 2008).

Autism: A developmental disability significantly affecting verbal and nonverbal communication and social interaction that adversely affects the student's educational performance. Other characteristics often associated with autism are engagement in repetitive activities, and stereotyped movements, resistance to environmental change or change in daily routine and unusual responses to sensory experiences.

Emotional or Behavioral Disorders: "Emotional disturbance" is used as a generic term to cover two types of behavior difficulties which are not mutually exclusive but which adversely affect educational performance: (1) Externalizing refers to behavior that are directed outwardly towards the social environment and usually involves behavioral excesses, and (2) Internalizing refers to a class of behavior problems that are directed inwardly and often involves behavior deficits.

Hearing Impairment - Deafness: Deafness is a hearing impairment so severe that the student is impaired in processing linguistic information through hearing, with or without amplification.

Inclusion: the practice of educating students with special needs in regular classes for all or nearly all of the day instead of in special education classes

Integration: the process of opening a group, community, place, or organization to all, regardless of ability. 
Intellectual Disability: A student who demonstrates sub-average intellectual functioning concurrently with deficits in adaptive behavior. Students with intellectual disabilities are those individuals who exhibit cognitive and adaptive behavior deficits that are likely to be life-long disabilities which can interfere with independent living. Learning Disability: A disorder in one of the basic psychological processes involved in understanding or in using language, spoken or written, which may manifest itself in an impaired ability to listen, think, speak, write, spell, or to do mathematical calculations. The term includes such conditions as perceptual disabilities, brain injury, minimal brain dysfunction, dyslexia and developmental aphasia.

Least Restrictive Environment: Having access to the general education curriculum, extracurricular activities, or any other program that non-disabled peers would be able to access.

Multiple Disabilities: Combination of two or more disabilities which causes severe educational deficit (such as intellectual disability-blindness; intellectual disabilityorthopedic impairment, etc.).

Orthopedic Impairment: A severe orthopedic impairment, the term includes impairments caused by congenital anomaly (e.g., clubfoot, absence of some member, etc.), impairment caused by disease (e.g., Poliomyelitis, bone tuberculosis, etc.), and impairments from other causes (e.g., cerebral palsy, amputations, and fractures or burns that cause contractures).

Perceived ability: The recognition of personal skill or competency level by teachers. Perceived ability refers to how well teachers think they can perform a specific task 
according to their own judgment and opinion.

Professional Development: The opportunity provided to teachers to develop, improve, collaborate, and/or enhance their knowledge, aptitudes, skills, and/or abilities through educational experiences. The opportunities are provided to teachers by teacher educators. Teachers are assessed as to what their needs or weaknesses are then teacher educators strive to provide educational experiences for teachers in order to advance their teaching ability.

$\underline{\text { Visual Impairment: }}$ Impairment in vision that, even with correction, adversely affects a student's educational performance. The term includes both partial sight and blindness.

\section{Assumptions}

The assumptions of this study included the following:

1. An adaptation of the Regular Education Initiative (REI) Survey by Phillips, Allred, Bruelle and Shank (1990) as modified by Gemmell-Crosby and Hanzlik (1994) was a valid method of assessing Utah Agricultural Education Teachers' a attitudes toward including students with disabilities in their classrooms and laboratories and determining their perceived ability to include students with disabilities in their classrooms and laboratories.

2. Utah agriculture teachers were familiar with the Individuals with Disabilities Education Act and the requirements of including students with disabilities; therefore, no explanation of the law was required. 
3. The responses from the agriculture teachers were accurate and the survey instrument was a valid and reliable tool for determining the inservice needs of agriculture teachers in Utah.

4. All agriculture teachers in the State of Utah were included in the population provided by the Utah State Office of Education.

\section{Limitations}

This research was conducted with the following limitations:

1. The individuals targeted as participants for this study were those teachers indentified as current Agricultural Educators by the Utah State Office of Education. Any other teachers in Utah matching the parameters of the population were not known and were therefore not part of the population studied.

2. The study utilized a written questionnaire instrument and the recruiting and follow-up procedures utilized electronic and postal mail services.

3. The use of a questionnaire limits the type of data collected and prohibits an indepth understanding of the respondents’ opinions and feelings. Questionnaires are generally inflexible and may not pose questions in a format understandable to all participants (Gall, Borg, \& Gall, 1996). 
Significance of the Study

According to the U.S. Department of Education's Office of Special Education (2008), just over 55,000 children with disabilities in the state of Utah are receiving special education assistance. The perceptions and abilities of agriculture educators toward inclusion of these students with disabilities have never been assessed. In order for the profession to provide students with disabilities a fair and least restrictive education teachers must be trained with sufficient knowledge and skills (Guralnick, 1982). The results of this study will provide data to better comprehend teachers attitudes, abilities, and needs toward inclusion. The information will supply guidance for providing professional development opportunities if the need is perceived as high priority by Utah agriculture educators. 


\section{CHAPTER II}

\section{REVIEW OF LITERATURE}

The purpose of this chapter is to provide an overview of the available literature dealing with the perceptions of agriculture teachers on including students with disabilities. Based on the review of literature, Chapter II has been divided into the following sections: (a) theoretical framework; (b) perceptions and attitudes toward inclusion; (c) skills and abilities of teachers; and (d) agricultural education for students with disabilities. Hand searches of The Agricultural Education Magazine, Journal of Agricultural Education and Journal of Career and Technical Education were performed. Information was obtained from the USU Library online databases using Google Scholar, ERIC and EBSCO host's Education collection. Searches were conducted using the following words or combination of words: perceptions, inclusion, disabilities, attitudes, mainstream, integration, agricultural education, and special education.

\section{Theoretical Framework}

In studying the perceptions of agriculture teachers toward including students with disabilities, the Theory of Reasoned Actions as proposed by Ajzen and Fishbein (1980) was utilized as the theoretical framework. In their model, Ajzen and Fishbein suggested that a person's behavior is reflected in their attitudes, and these behaviors are developed from personal beliefs, perceptions, and intentions. Some of these beliefs come from direct experience while others are inferred or self generated. Only a few of these beliefs work to influence one's attitude. These are referred to as salient beliefs. Within the interpretation 
of this research, the theory was applied by considering how agriculture teachers' experiences and characteristics coincide with their attitudes and perceptions. As indicated by Fishbein and Ajzen (1975), past experiences influence salient beliefs and in turn are reflected in their attitudes regarding the inclusion of students with disabilities in their classroom or laboratory. Based on this theory a conceptual model was developed as shown in Figure 1.

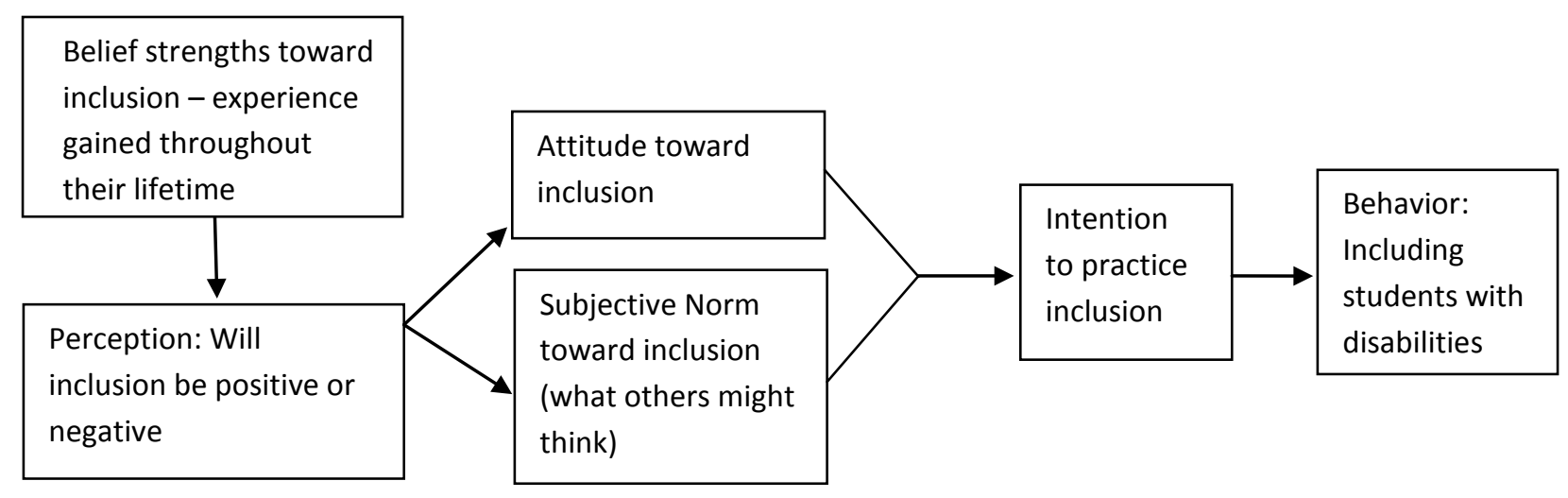

Figure 1. The influence of beliefs, perceptions, and attitudes toward inclusion on intentions and behaviors.

\section{Attitudes toward Inclusion}

Research has suggested that teachers’ perceptions and attitudes toward inclusion affect the successful implementation of inclusive education. Attitudinal data collected by Ward, Center, and Bochner (1994) from six different groups of educators suggested that attitudes are greatly affected by the nature of the disability and/or education problems that exist. 
Mittler (2003) reported at the International Special Education conference held in 2000 that a common theme among many research papers and posters from more than 99 countries was that "the biggest single obstacle to progress is not money or lack of legislation but negative attitudes on the part of many parents, teachers, community leaders, and politicians” (p. 3).

Recent research by Pivik, and collegues (2002) examined whether special education efforts are truly meeting the needs of the students and if the convictions of inclusion are reflected in the actions of teachers. Parents and students were asked to identify barriers to inclusion. Parents identified teachers' attitudes as the major obstacle. The researchers posited that teacher attitudes are by far the most detrimental component in allowing students with special needs to succeed. Therefore, one of the most valuable elements in the inclusion process is a positive attitude of the teachers.

Center and Ward (1987) surveyed regular and resource teachers from New South Wales on their attitudes toward integration of students with disabilities. Overall, a negative attitude was displayed toward integrating students with behavioral or educational disabilities. Favorable attitudes were exhibited only toward mainstreaming students whose disability did not require extra effort on the part of the teacher. It was evident in the results that teachers' attitude toward inclusion was greatly impacted by the lack of confidence the teachers had in their own instructional skills and by support personnel available. An interesting finding in the study, although not of great significance and should be treated with care, was that it appeared that the teachers in the Catholic systemic schools portrayed a more positive attitude toward inclusion. 
Williams and Algozzine (1979) explored teachers' reasons for attitudes on several aspects of special education and mainstreaming. Teachers responded to two sets of questions; the first set asked them to select reasons why they felt capable to teach handicapped children and the second set of questions was to obtain information on why teachers would not voluntarily mainstream handicapped children. One of the themes in the results was that teachers who had had a previous positive experience felt confident in their abilities and had an optimistic attitude toward inclusion. The teachers that were not willing to include handicapped children stated that they felt that integration was a disruption to the other students in the class and took away from their learning experience and that they lacked the technical ability to be effective.

Berryman (1989) investigated the publics' attitude toward education mainstreaming. In a small city shopping mall 377adults were surveyed. The findings of this survey were judged against the results from a prior survey of pre-service and inservice teachers. Attitudes toward mainstreaming in general were positive unless the students would have difficulty functioning in a normal classroom setting. It was concluded that the general public appeared to have a positive attitude toward mainstreaming but general educators have not yet developed a compassionate perception toward students with special needs nor do they support inclusion into regular classrooms. A change in attitude following in-service training was reflected in results reported by Dickens-Smith (1995). Respondents were given an attitudinal survey before and after staff development. After the in-service training both groups of respondents revealed more favorable attitudes toward inclusion than they did at the beginning of the workshop, with 
regular education teachers showing the strongest positive attitude change. DickensSmith concluded that "staff development is the key to the success of inclusion" (p. 8).

These studies have indicated that teacher attitudes affect the success of including students with special needs it is also noted that attitudes generally reflect teachers perceived ability and skill level.

Perceptions of Skills and Abilities of Including

Students with Disabilities

Center and Ward’s (1987) Australian study with regular classroom teachers indicated that

their attitudes to integration reflected lack of confidence both in their own instructional skills and in the quality of support personnel available to them. They were positive about integrating only those children whose disabling characteristics were not likely to require extra instructional or management skills on the part of the teacher. (p. 41)

Hudson et al. (1979) surveyed elementary school regular class teachers to extract their attitudes and perceptions of time, materials, skills, support services, and training needs regarding mainstreaming of exceptional children. They discovered that the more unfavorable attitudes of the teachers stemmed from the teachers' perceptions of lack of time, support services or the necessary training. The teachers believed that additional training would be very beneficial with a strong conformity that in-service and pre-service training is a key component. They found that if regular classroom teachers' views were 
not desirable regarding inclusion, the entire success of the program would be in jeopardy. They stated that in order to adjust these perspectives it is fundamentally important to provide teachers with the appropriate professional development to intensify their level of skill competency and to boost their attitudes.

Werts et al. (1996) found that training issues, or lack thereof, was listed frequently as a critical support problem. The study consisted of two mailed surveys of Pennsylvania teachers to determine a consensus of general education teachers and special education teachers on conditions and supports needed, and the problems facing inclusion. In the study the teachers were asked to list three major problems they encounter when including students with disabilities. The most frequent concern listed was the lack of training and the inability to meet the needs of the students.

Avramidis and Norwich (2002) concluded that attitudes toward implementation changed dramatically if appropriate professional development was offered. They suggested that it is vital to have a progressive and consistent plan for teachers' professional development to help facilitate educating students with disabilities and to develop a more positive attitude toward inclusion amongst educators.

It is apparent that it is critical to provide proper training and professional development for teachers in order to meet the needs of all students, regardless of disabilities or curriculum interest. 
Agricultural Education for Students with Disabilities

Brandon and Ncube (2006) conducted a study of agriculture teachers' and their attitudes towards inclusion of students with physical disabilities in mainstream classes in Botswana. They found that

although agriculture teachers were neutral in their attitude towards the overall inclusion of students with physical disabilities into mainstream classes, their attitudes towards the teaching and classroom management of students with physical disabilities were negative. Teachers indicated that they do not have sufficient training, nor do they possess the expertise necessary to teach students with physical disabilities. (p. 224)

Brandon and Ncube (2006) continued:

Agriculture is one of the few practical subjects in Botswana that is compulsory for all students to take and because it requires a great number of hands-on activities, agriculture teachers' attitude towards inclusion of students with physical disabilities into their classes can have either positive or negative consequences on the students enrolled as well as the agriculture program in Botswana. (p. 217) In an article in the Agricultural Education Magazine by Cooper, Bocksnick, and Frick (2002) noted that there is a great deal of shop/laboratory experiences built into the curriculum. In a shop/laboratory setting, the most pressing concern with all students is safety. When special needs students are included in classes, this concern should be heightened. These types of situations require prior planning and preparation by the teacher. It is important to have special needs students participate along side the 
mainstreamed students conducting the same activities at the same time. Simple modifications of activities may be required such as customized projects to create handson, real life experiences that will benefit all students. However, most strategies for integrating special needs involve merely a reminder to treat those students the same as the other students in the class.

Dormody et al. (2006) conducted a study of the challenges that face New Mexico Agricultural Education teachers when including students with special needs. The participants were asked to rank types of disabilities and the challenges they face based on the format of their classroom. Eighty-five percent of the respondents had a combination classroom and shop/laboratory, 59\% had a classroom only and approximately $45 \%$ of the programs were a shop/laboratory only. For classes that included utilization of the shop or laboratory, they rated students with mental retardation, physical disabilities, and emotional behavioral disorders as the most challenging. But on average, all types of special education were rated as little or moderately challenging to include students. The findings showed that the older the teacher the less challenging they perceived including students in a classroom. The teachers indicated that the more prepared they were to teach students with special needs the less frustrating it was. Teachers who had more formal course work on inclusion also felt it was less challenging to include students with disabilities.

Georgia agriculture teachers reflected on their experience and skills to help determine the professional development needs and priorities of the teachers. They were asked to identify specifically what they needed to help them teach and learn. The Georgia 
agriculture teachers ranked "teaching learning disabled students" as the fourth most important focus area of professional development needed in their area (Ricketts \& Duncan, 2005).

Pennsylvania agriculture instructors were asked by Elbert and Baggett (2003) to indicate their perceived competency level for working with disabled students. The five competencies that were rated the lowest included: (1) completing individual vocational education plans, ( 2) being familiar with laws that apply to special needs students, (3) completing individual education plans, (4) assisting the student in viewing his/her assets or limitations realistically, and (5) utilizing a variety of methods and techniques to provide instruction for disabled students. Teachers indicated that their desired proficiency level was higher than their current perceived proficiency level. They stated that most agricultural educators feel less competent while working with disabled student, and an increase in participation in agricultural education courses by disabled students will require additional training. Elbert and Bagget shared a valuable impactions, from their study “many students in Pennsylvania may not be adequately served because of poor teaching, social and professional skills of teachers as reflected by their perceived levels of competence.” They concluded that the agriculture education population as a whole would benefit by appropriate professional development on working with students with special needs and that these students in turn would have a successful experience and make a positive contribution to society. 
Summary

Although a study specifically measuring Utah agricultural educators perceptions of including students with disabilities has never been conducted, a study conducted by Sorenson, Tarpley, and Warnick (2005) reviewed the in-service needs of Utah agricultural educators. It suggested that teachers perceive themselves as having low levels of ability in teaching students with learning disabilities.

The U.S. Department of Education (1994) found an increasingly higher proportion of special needs students enrolled in agricultural education classes than other technical education classes. Also, in Utah the U.S. Department of Education's Office of Special Education (2008) reports just over 55,000 children with disabilities are receiving special education assistance.

In reviewing the literature, studies have indicated that teacher attitudes affect the success of including students with special needs. In general there is literature available that addresses the needs of including students with disabilities in general education classrooms. However, few studies specifically addressed the attitudes and abilities of agriculture teachers. Moreover, limited research is available on teachers’ perceived abilities and attitudes toward specific types of disabilities.

Teachers’ attitudes toward inclusion are generally based on the perception or fear of the many variables that are attached to inclusion. Success in this area will require teachers to overcome this fear through self-assurance, experience and professional development (Dormody et al., 2006). 
Further assessment of the attitudes and aptitudes of Utah agriculture teachers toward inclusion is vital, in order that appropriate accommodations be made for these students. 


\section{CHAPTER III}

\section{PROCEDURES}

The purpose of this study was to assess Utah agricultural education teachers’ attitudes toward including students with disabilities in their classrooms and laboratories and to determine their perceived ability to include students with disabilities in their classrooms and laboratories. The results of this study will help teacher educators and state leaders provide effective professional development based on current perceptions, abilities and needs of including students with disabilities in agricultural classrooms and laboratories.

\section{Objectives}

There were eleven objectives identified for this study:

1. Describe the demographic profile of Utah secondary agriculture teachers;

2. Determine the perceived attitudes and ability of Utah agriculture teachers concerning the inclusion of students with disabilities;

3. Determine the perceived security level of Utah agriculture teachers concerning the inclusion of students with disabilities;

4. Determine the willingness of Utah agriculture teachers to include students with specific disabilities;

5. Determine the skill set of Utah agriculture teachers to include students with specific disabilities; 
6. Determine the satisfaction level of Utah agriculture teachers with available support services;

7. Determine the willingness of Utah agriculture teachers to participate in professional development regarding inclusion activities;

8. Describe how students with special needs are included in the Utah agriculture teachers’ classroom/laboratories;

9. Summarize the education/professional development Utah agriculture teachers have received regarding inclusion;

10. List the support services available to the Utah agriculture teachers; and

11. Correlate selected demographic variables with the perceptions of Utah agriculture teachers toward the inclusion of students with disabilities.

\section{Instrumentation}

Descriptive survey methods were used to explore the attitudes and aptitudes of agricultural education teachers in Utah $(N=93)$ related to including students with special needs. The instrument used in this study is an adaptation of the Regular Education Initiative (REI) Survey by Phillips et al. (1990) as modified by Gemmell-Crosby and Hanzlik (1994). The adapted questionnaire used in this study was revised to more accurately reflect the classroom and laboratory of an agriculture teacher (see Appendix A). Evidence of face and content validity was acquired by a panel of experts consisting of university agriculture teacher educators, special education teacher educators, and a state supervisor of agricultural education. Terms used in the instrument were modified to 
reflect current terminology used by the Utah education department and were defined in the questionnaire (Utah State Office of Education, 2008).

The instrument consisted of four sections. Section I requested information about selected personal and professional characteristics from the participants. Section II obtained information about the teachers' attitudes toward including students with disabilities in their classrooms and laboratories, perceptions of adequacy of support services, and their perceived ability and willingness to include students with specific disabilities. Each statement asked the teachers to rate their response on a 5-point Likerttype scale, from “strongly agree” to “strongly disagree.” Section III addressed the teachers' satisfaction with support services and the education they received or are currently receiving regarding the inclusion of students with disabilities. The same Likerttype scale was used for this section as in Section II. Section IV consisted of two open ended questions to provide a forum for teachers’ comments regarding inclusion, education and training, and supportive services.

\section{Selection of Population}

All agriculture teachers in Utah $(N=93)$ were selected as the target population for this study. The state supervisor of agricultural education in the state department of education provided the researchers with a current database containing the names and addresses of all Utah agriculture teachers. All teachers included in the population were invited to participate. The individuals targeted as participants for this study were those teachers indentified as current Agricultural Educators by the state educational agency. 
Any other teachers matching the parameters of the population were not known and were therefore not part of the population studied.

\section{Collection of Data}

The questionnaire and a letter of information were presented to teachers at the Utah Association of Agricultural Educators Fall Conference on October 16, 2008, and the teachers in attendance were asked to complete the questionnaire. On October 27, 2008, teachers not attending the Fall Conference were sent a pre-notice electronic letter requesting their participation (see Appendix B). According to Dillman (2000), pre-notice letters improve survey response rate. Questionnaire packets containing an information letter (see Appendix C) and a stamped, self-addressed return envelope were then sent on October 29, 2008. Thank-you/reminder postcards expressing appreciation to respondents and encouraging non-respondents to reply as suggested by Dillman were then sent November 7, 2008 (see Appendix D). A follow-up replacement packet was sent to nonrespondents on November 21, 2008 (see Appendix E). Instructions for completion and submission of the survey and deadline dates were included in the cover letter and on the instrument. Institutional Review Board (IRB) approval was obtained prior to conducting the survey.

\section{Data Analysis}

The first research objective was statistically analyzed using descriptive statistics including frequency, percentages, mean and standard deviation. Objectives two through 
seven used descriptive statistics including frequency, percentages, and medians. The comments were written verbatim in association with objectives eight to ten (see Appendix F). Analysis of the response to the open-ended questions was conducted through a process of individual initial coding by multiple analysts and then negotiation of a formal coding scheme, followed by individual recoding data. Themes were then identified separately and comparisons made using convergent coding (Patton, 2002) A series of multiple regression analyses was utilized to determine if any significant relationship existed for objective eleven. A priori alpha level was set at .05. A post hoc analysis using Cronbach’s alpha was conducted to estimate reliability of the instrument. 


\section{CHAPTER IV \\ RESULTS AND FINDINGS}

The purpose of this study was to assess Utah agricultural education teachers' attitudes toward including students with disabilities in their classrooms and laboratories and to determine their perceived ability to include students with disabilities in their classrooms and laboratories. The results of this study will help teacher educators and state leaders provide effective professional development based on current perceptions, abilities and needs of including students with disabilities in agricultural classrooms and laboratories.

The number of responses from the defined population of agriculture teachers in Utah $(N=93)$ was 78 for a response rate of $(83.9 \%)$. A post hoc reliability analysis of the survey instrument was performed to determine if the instrument had an acceptable reliability value. Internal consistency was estimated at .933 using Cronbach’s alpha.

There were three respondent groups identified in this study. There were forty participants (43.0\%) that completed the survey at a professional development conference for agriculture teachers and 38 participants (40.9\%) completed the survey by mail. Lindner, Murphy, and Briers (2001) recommended comparing early and late respondents as a method for handling non-response. Participants completing the survey following the initial mailing were identified as early respondents $(n=31 ; 32.2 \%)$ and those completing the survey after the second reminder were identified as late respondents $(n=7 ; 7.5 \%)$. To determine if differences existed between any of the three groups (conference, early responders, and later responders), the participants' scaled responses were summed and an 
analysis of variance (ANOVA) was calculated. The results indicated no statistically significant differences between any of the three groups, $F(2,75)=0.593, p=.555$. Eleven objectives were established to achieve the purpose of this study. The objectives were to:

1. Describe the demographic profile of Utah secondary agriculture teachers;

2. Determine the perceived attitudes and ability of Utah agriculture teachers concerning the inclusion of students with disabilities;

3. Determine the perceived security level of Utah agriculture teachers concerning the inclusion of students with disabilities;

4. Determine the willingness of Utah agriculture teachers to include students with specific disabilities;

5. Determine the skill set of Utah agriculture teachers to include students with specific disabilities;

6. Determine the satisfaction level of Utah agriculture teachers with available support services;

7. Determine the willingness of Utah agriculture teachers to participate in professional development regarding inclusion activities;

8. Describe how students with special needs are included in the Utah agriculture teachers' classroom/laboratories;

9. Summarize the education/professional development Utah agriculture teachers have received regarding inclusion;

10. List the support services available to the Utah agriculture teachers; and 
11. Correlate selected demographic variables with the analyzed perceptions of Utah agriculture teacher on inclusion of students with disabilities.

\author{
Objective One: Describe the Demographic Profile of \\ Utah Secondary Agriculture Teachers
}

The typical Utah agriculture teacher was 36.35 years old $(S D=10.97)$, had 10.38 years of teaching experience $(S D=9.05)$, and had 9.47 years of experience teaching students with disabilities $(S D=8.91)$. The respondents consisted of 22 females $(28.2 \%)$ and 56 males (71.8\%). Overall, 27 (34.6\%) of the teachers taught in a rural community (population less than 2,500), 40 (51.3\%) taught in a suburban community (population of 2,500 - 49,999), and 11 (14.1\%) taught in an urban community (population greater than 50,000). Of the respondents fifteen (19.3\%) of them held a bachelor's degree as their highest level of education, 29 (37.2\%) held a bachelor's degree plus additional credit hours, 13 (16.7\%) held a master's degree, and 19 (24.4\%) held a master's degree plus additional credit hours. Of the respondents, 75 (96.2\%) indicated they had participated in the IEP process with 3 (3.5\%) reporting they had not participated in this process. The mean number of special education courses taken on a University level was $1.34(S D=$ 1.07), and the mean number of professional development workshops attended was 1.21 $(S D=2.18)$.

The instrument had the respondents indicate all of the related service providers that they worked with. Table 1 lists the responses for each provider. 
Table 1

Special Education Service Providers Utilized by Agricultural Teachers

\begin{tabular}{lcc}
\hline Type of Service Provider & $N$ Worked With & $\%$ \\
\hline Special Education Teacher & 71 & 91 \\
Speech Language Pathologist & 29 & 37.2 \\
Other (psychologist, nurse, etc.) & 28 & 35.9 \\
Occupational Therapist & 21 & 26.9 \\
Physical Therapist & 13 & 16.7
\end{tabular}

Objective Two: Determine the Perceived Attitudes and Ability of Utah Agriculture Teachers Concerning the Inclusion of Students with Disabilities

Participants were asked to indicate their perceived skill level, understanding and security level of including students with special needs in their classroom/laboratory. These findings are summarized in Table 2. Nearly 90\% of participants agreed or strongly agreed that they understood the concept of inclusion yet only $61.5 \%$ agreed or strongly agreed that students with disabilities should be integrated into the regular classroom. Slightly over half of the participants believed they had the skills to successfully include students with disabilities.

The teachers indicated they understood inclusion, agreed that students with special needs should be included in their classrooms and they personally were in favor of inclusion. No teacher strongly disagreed with the concept of inclusion. It was evident that 
Table 2

Skill Level and Understanding of Including Students with Disabilities

\begin{tabular}{|c|c|c|c|c|c|c|}
\hline Question & $\begin{array}{c}\text { SA } \\
f \\
\% \\
\end{array}$ & $\begin{array}{c}\text { A } \\
f \\
\%\end{array}$ & $\begin{array}{c}\mathrm{N} \\
f \\
\%\end{array}$ & $\begin{array}{l}\mathrm{D} \\
f \\
\%\end{array}$ & $\begin{array}{c}\text { SD } \\
f \\
\%\end{array}$ & Median \\
\hline $\begin{array}{l}\text { I understand the concept of } \\
\text { inclusion/integration. }\end{array}$ & $\begin{array}{c}21 \\
26.9\end{array}$ & $\begin{array}{c}49 \\
62.8\end{array}$ & $\begin{array}{c}6 \\
7.7\end{array}$ & $\begin{array}{c}1 \\
1.3\end{array}$ & $\begin{array}{c}0 \\
0.0\end{array}$ & 4 \\
\hline $\begin{array}{l}\text { The size of the class needs to be lowered } \\
\text { when students with disabilities are } \\
\text { included. }\end{array}$ & $\begin{array}{c}43 \\
55.1\end{array}$ & $\begin{array}{c}21 \\
26.9\end{array}$ & $\begin{array}{c}9 \\
11.5\end{array}$ & $\begin{array}{c}4 \\
5.1\end{array}$ & $\begin{array}{c}0 \\
0.0\end{array}$ & 5 \\
\hline $\begin{array}{l}\text { I am in favor of including students with } \\
\text { disabilities in my class. }\end{array}$ & $\begin{array}{c}22 \\
28.2\end{array}$ & $\begin{array}{c}38 \\
48.7\end{array}$ & $\begin{array}{c}13 \\
16.7\end{array}$ & $\begin{array}{c}1 \\
1.3\end{array}$ & $\begin{array}{c}0 \\
0.0\end{array}$ & 4 \\
\hline $\begin{array}{l}\text { Students with disabilities should be } \\
\text { integrated into general school classes } \\
\text { for typically developing students } \\
\text { rather than attending special education } \\
\text { classes. }\end{array}$ & $\begin{array}{c}11 \\
14.1\end{array}$ & $\begin{array}{c}37 \\
47.4\end{array}$ & $\begin{array}{c}23 \\
29.5\end{array}$ & $\begin{array}{c}6 \\
7.7\end{array}$ & $\begin{array}{c}0 \\
0.0\end{array}$ & 4 \\
\hline $\begin{array}{l}\text { The inclusion of students with special } \\
\text { needs into regular classes will take } \\
\text { much of the teacher's time and } \\
\text { attention from typically developing } \\
\text { students. }\end{array}$ & $\begin{array}{c}12 \\
15.4\end{array}$ & $\begin{array}{c}31 \\
39.7\end{array}$ & $\begin{array}{c}19 \\
24.4\end{array}$ & $\begin{array}{c}15 \\
19.2\end{array}$ & $\begin{array}{c}0 \\
0.0\end{array}$ & 4 \\
\hline $\begin{array}{l}\text { I presently have the skills to successfully } \\
\text { include students with disabilities in my } \\
\text { classroom. }\end{array}$ & $\begin{array}{c}12 \\
15.4\end{array}$ & $\begin{array}{c}29 \\
37.2\end{array}$ & $\begin{array}{c}22 \\
28.2\end{array}$ & $\begin{array}{c}13 \\
16.7\end{array}$ & $\begin{array}{c}1 \\
1.3\end{array}$ & 4 \\
\hline
\end{tabular}

Note. $\mathrm{SA}=$ Strongly Agree; $\mathrm{A}=$ Agree; $\mathrm{N}=$ Neutral; $\mathrm{D}=$ Disagree, $\mathrm{SD}=$ Strongly Disagree 
class size was important to teachers and more than half believed that class size should be lower if there are students with disabilities in the class. The greater part of the respondents in this study believed that they presently have the skills to successfully include students with disabilities in their classes, yet indicated that it does require more time and takes away from typically developing students in their class.

Objective Three: Determine the Perceived Security Level of Utah Agriculture Teachers Concerning the Inclusion of Students with Disabilities

The instrument had the respondents indicate their security level regarding the ability to include students with special needs in their classroom/laboratory Table 3 lists the rankings for each questions.

Table 3

Security Regarding Ability Concerning the Inclusion of Students with Disabilities

\begin{tabular}{|c|c|c|c|c|c|c|}
\hline Questions & $\begin{array}{c}\text { SA } \\
f \\
\%\end{array}$ & $\begin{array}{c}\text { A } \\
f \\
\%\end{array}$ & $\begin{array}{c}\mathrm{N} \\
f \\
\%\end{array}$ & $\begin{array}{l}\mathrm{D} \\
f \\
\%\end{array}$ & $\begin{array}{l}\text { SD } \\
f \\
\%\end{array}$ & Median \\
\hline $\begin{array}{l}\text { A regular classroom setting is probably the } \\
\text { best placement for students with mild } \\
\text { level of need. }\end{array}$ & $\begin{array}{c}36 \\
46.2\end{array}$ & $\begin{array}{c}40 \\
51.3\end{array}$ & $\begin{array}{c}2 \\
2.6\end{array}$ & $\begin{array}{c}0 \\
0.0\end{array}$ & $\begin{array}{c}0 \\
0.0\end{array}$ & 4 \\
\hline $\begin{array}{l}\text { My experience in teaching students with } \\
\text { disabilities has been mostly positive. }\end{array}$ & $\begin{array}{c}21 \\
26.9\end{array}$ & $\begin{array}{c}43 \\
55.1\end{array}$ & $\begin{array}{c}10 \\
12.8\end{array}$ & $\begin{array}{c}4 \\
5.1\end{array}$ & $\begin{array}{c}0 \\
0.0\end{array}$ & 4 \\
\hline $\begin{array}{l}\text { I feel comfortable participating in Individual } \\
\text { Education Plan (IEP) Conferences. }\end{array}$ & $\begin{array}{c}34 \\
43.6\end{array}$ & $\begin{array}{c}29 \\
37.2\end{array}$ & $\begin{array}{c}13 \\
16.7\end{array}$ & $\begin{array}{c}2 \\
2.6\end{array}$ & $\begin{array}{c}0 \\
0.0\end{array}$ & 4 \\
\hline $\begin{array}{l}\text { I feel secure in my abilities to interpret } \\
\text { assessment results. }\end{array}$ & $\begin{array}{c}19 \\
24.4\end{array}$ & $\begin{array}{c}39 \\
50.0\end{array}$ & $\begin{array}{c}14 \\
17.9\end{array}$ & $\begin{array}{c}6 \\
7.7\end{array}$ & $\begin{array}{c}0 \\
0.0\end{array}$ & 4 \\
\hline
\end{tabular}


I feel I can create a safe environment in my classroom/laboratory for all students when including students with disabilities.

A regular classroom setting is probably the best placement for students with moderate level of need.

I feel secure in my abilities to adapt materials/curriculum for students with disabilities.

I feel secure in managing behavior problems related to students with disabilities.

I feel secure in my abilities to work with parents of students with disabilities.

The extra paperwork and time needed for students with disabilities (accommodations, IEP forms) are not a problem.

A regular classroom setting is probably the best placement for students with significant level of need.

There is very little difference in the curriculum when a student with special needs is included in the class or group.

In my classroom, teacher/student ratios are adequate or appropriate for mainstreaming children with disabilities.

$\begin{array}{llllll}12 & 44 & 11 & 9 & 2 & 4\end{array}$

$\begin{array}{lllll}15.4 & 56.4 & 14.1 & 11.5 & 2.6\end{array}$

4

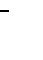


For the most part, teachers either agreed or were neutral in their level of security in teaching students with disabilities, appropriately adapting materials, and working with parents. Teachers expressed a comfort level with respect to including students with mild or moderate levels of need. However it was clear that teachers were not comfortable including students with a significant level of need. Class size appeared as an important factor. Teachers indicated that their current class sizes or student/teacher ratio was appropriate for including students with disabilities. They did not feel as though the curriculum varied much from the regular students and that the paper work was not a problem. Overall, the majority of teachers have had a positive experience when working with students with disabilities.

Objective Four: Determine the Willingness of Utah Agriculture Teachers to Include Students with Specific Disabilities

The instrument had the respondents indicate their level of willingness to include students with specific special needs. Table 4 lists the rankings for each specific disability.

It was apparent that teachers are willing to include students with a variety of disabilities. Over $85 \%$ of the teachers indicated that that they were willing to include students with a learning disability, an orthopedic impairment, hearing impairment/deafness or an intellectual disability. Teachers indicated being less willing to include students with emotional or behavior disorders and students with multiple disabilities. 
Table 4

Teachers' Willingness to Include Student with Disabilities

\begin{tabular}{|c|c|c|c|c|c|c|}
\hline Question & $\begin{array}{c}\text { SA } \\
f \\
\%\end{array}$ & $\begin{array}{c}\text { A } \\
f \\
\%\end{array}$ & $\begin{array}{c}\mathrm{N} \\
f \\
\%\end{array}$ & $\begin{array}{l}\mathrm{D} \\
f \\
\%\end{array}$ & $\begin{array}{l}\text { SD } \\
f \\
\%\end{array}$ & Median \\
\hline $\begin{array}{l}\text { I am willing to include students with a } \\
\text { learning disability in my } \\
\text { classroom/laboratory. }\end{array}$ & $\begin{array}{c}26 \\
33.3\end{array}$ & $\begin{array}{c}45 \\
57.7\end{array}$ & $\begin{array}{c}4 \\
5.1\end{array}$ & $\begin{array}{c}1 \\
1.3\end{array}$ & $\begin{array}{c}0 \\
0.0\end{array}$ & 4 \\
\hline $\begin{array}{l}\text { I am willing to include students with an } \\
\text { orthopedic impairment in my } \\
\text { classroom/laboratory. }\end{array}$ & $\begin{array}{c}24 \\
30.8\end{array}$ & $\begin{array}{c}45 \\
57.7\end{array}$ & $\begin{array}{c}7 \\
9.0\end{array}$ & $\begin{array}{c}1 \\
1.3\end{array}$ & $\begin{array}{c}0 \\
0.0\end{array}$ & 4 \\
\hline $\begin{array}{l}\text { I am willing to include students with a } \\
\text { hearing impairment/deafness in my } \\
\text { classroom/laboratory. }\end{array}$ & $\begin{array}{c}25 \\
32.1\end{array}$ & $\begin{array}{c}43 \\
55.1\end{array}$ & $\begin{array}{c}1 \\
1.3\end{array}$ & $\begin{array}{c}8 \\
10.3\end{array}$ & $\begin{array}{c}1 \\
1.3\end{array}$ & 4 \\
\hline $\begin{array}{l}\text { I am willing to include students with an } \\
\text { intellectual disability in my } \\
\text { classroom/laboratory. }\end{array}$ & $\begin{array}{c}19 \\
24.4\end{array}$ & $\begin{array}{c}47 \\
60.3\end{array}$ & $\begin{array}{c}7 \\
9.0\end{array}$ & $\begin{array}{c}4 \\
5.1\end{array}$ & $\begin{array}{c}0 \\
0.0\end{array}$ & 4 \\
\hline $\begin{array}{l}\text { I am willing to include students with autism } \\
\text { in my classroom/laboratory. }\end{array}$ & $\begin{array}{c}13 \\
16.7\end{array}$ & $\begin{array}{c}44 \\
56.4\end{array}$ & $\begin{array}{c}14 \\
17.9\end{array}$ & $\begin{array}{c}5 \\
6.4\end{array}$ & $\begin{array}{c}1 \\
1.3\end{array}$ & 4 \\
\hline $\begin{array}{l}\text { I am willing to include students with visual } \\
\text { impairment (includes blind) in my } \\
\text { classroom/laboratory. }\end{array}$ & $\begin{array}{c}18 \\
23.1\end{array}$ & $\begin{array}{c}34 \\
43.6\end{array}$ & $\begin{array}{c}17 \\
21.8\end{array}$ & $\begin{array}{c}6 \\
7.7\end{array}$ & $\begin{array}{c}2 \\
2.6\end{array}$ & 4 \\
\hline $\begin{array}{l}\text { I am willing to include students with an } \\
\text { emotional or behavioral disorder in my } \\
\text { classroom/laboratory. }\end{array}$ & $\begin{array}{c}14 \\
17.9\end{array}$ & $\begin{array}{c}38 \\
48.7\end{array}$ & $\begin{array}{c}21 \\
26.9\end{array}$ & $\begin{array}{c}3 \\
3.8\end{array}$ & $\begin{array}{c}1 \\
1.3\end{array}$ & 4 \\
\hline $\begin{array}{l}\text { I am willing to include students with } \\
\text { multiple disabilities in my } \\
\text { classroom/laboratory. }\end{array}$ & $\begin{array}{c}14 \\
17.9\end{array}$ & $\begin{array}{c}36 \\
46.2\end{array}$ & $\begin{array}{c}17 \\
21.8\end{array}$ & $\begin{array}{c}9 \\
11.5\end{array}$ & $\begin{array}{c}1 \\
1.3\end{array}$ & 4 \\
\hline
\end{tabular}

Note. SA = Strongly Agree; $\mathrm{A}=$ Agree; $\mathrm{N}=$ Neutral; $\mathrm{D}=$ Disagree, $\mathrm{SD}=$ Strongly Disagree 
Objective Five: Determine the Skill Set of Utah Agriculture Teachers to Include Students with Specific Disabilities

The instrument had the respondents indicate their skill level to successfully include students with specific special needs. Table 5 lists the rankings for each category. In reviewing the responses it appeared that teachers were not secure in their skill levels when including students with disabilities. Teachers indicated being more confident in their skills of including students with a learning disability with $76.9 \%$ strongly agreeing or agreed that they possess the skills needed. Teachers were the least confident when including students with autism or a visual impairment.

Objective Six: Determine the Satisfaction Level of Utah Agriculture Teachers with Available Support Services

Participants were asked to indicate the level of support services that they currently received or those which they needed more of. Table 6 indicates the rankings for each question. 


\section{Table 5}

Teachers Perceived Skill Set When Including Students with Specific Disabilities

\begin{tabular}{|c|c|c|c|c|c|c|}
\hline Question & $\begin{array}{l}\text { SA } \\
f \\
\%\end{array}$ & $\begin{array}{c}\text { A } \\
f \\
\%\end{array}$ & $\begin{array}{l}\mathrm{N} \\
f \\
\%\end{array}$ & $\begin{array}{l}\mathrm{D} \\
f \\
\%\end{array}$ & $\begin{array}{l}\text { SD } \\
f \\
\%\end{array}$ & Median \\
\hline $\begin{array}{l}\text { I presently have the skills to include } \\
\text { students with a learning disability in } \\
\text { my classroom/laboratory. }\end{array}$ & $\begin{array}{c}14 \\
17.9\end{array}$ & $\begin{array}{c}46 \\
59.0\end{array}$ & $\begin{array}{c}12 \\
15.4\end{array}$ & $\begin{array}{c}5 \\
6.4\end{array}$ & $\begin{array}{c}1 \\
1.3\end{array}$ & 4 \\
\hline $\begin{array}{l}\text { I presently have the skills to include } \\
\text { students with an intellectual disability } \\
\text { in my classroom/laboratory. }\end{array}$ & $\begin{array}{c}9 \\
11.5\end{array}$ & $\begin{array}{c}40 \\
51.3\end{array}$ & $\begin{array}{c}15 \\
19.2\end{array}$ & $\begin{array}{c}11 \\
14.1\end{array}$ & $\begin{array}{c}2 \\
2.6\end{array}$ & 4 \\
\hline $\begin{array}{l}\text { I presently have the skills to include } \\
\text { students with an orthopedic impairment } \\
\text { in my classroom/laboratory. }\end{array}$ & $\begin{array}{c}11 \\
14.1\end{array}$ & $\begin{array}{c}35 \\
44.9\end{array}$ & $\begin{array}{c}22 \\
28.2\end{array}$ & $\begin{array}{c}8 \\
10.3\end{array}$ & $\begin{array}{c}2 \\
2.6\end{array}$ & 4 \\
\hline $\begin{array}{l}\text { I presently have the skills to include } \\
\text { students with an emotional or } \\
\text { behavioral disorder in my } \\
\text { classroom/laboratory. }\end{array}$ & $\begin{array}{c}7 \\
9.0\end{array}$ & $\begin{array}{c}33 \\
42.3\end{array}$ & $\begin{array}{c}19 \\
24.4\end{array}$ & $\begin{array}{c}16 \\
20.5\end{array}$ & $\begin{array}{c}2 \\
2.6\end{array}$ & 3.75 \\
\hline $\begin{array}{l}\text { I presently have the skills to include } \\
\text { students with a hearing } \\
\text { impairment/deafness in my } \\
\text { classroom/laboratory. }\end{array}$ & $\begin{array}{c}6 \\
7.7\end{array}$ & $\begin{array}{c}30 \\
38.5\end{array}$ & $\begin{array}{c}25 \\
32.1\end{array}$ & $\begin{array}{c}15 \\
19.2\end{array}$ & $\begin{array}{c}2 \\
2.6\end{array}$ & 3 \\
\hline $\begin{array}{l}\text { I presently have the skills to include } \\
\text { students with multiple disabilities in my } \\
\text { classroom/laboratory. }\end{array}$ & $\begin{array}{c}2 \\
2.6\end{array}$ & $\begin{array}{c}29 \\
37.1\end{array}$ & $\begin{array}{c}25 \\
32.1\end{array}$ & $\begin{array}{c}19 \\
24.4\end{array}$ & $\begin{array}{c}3 \\
3.8\end{array}$ & 3 \\
\hline $\begin{array}{l}\text { I presently have the skills to include } \\
\text { students with autism in my } \\
\text { classroom/laboratory. }\end{array}$ & $\begin{array}{c}7 \\
9.0\end{array}$ & $\begin{array}{c}22 \\
28.2\end{array}$ & $\begin{array}{c}24 \\
30.8\end{array}$ & $\begin{array}{c}19 \\
24.4\end{array}$ & $\begin{array}{c}6 \\
7.7\end{array}$ & 3 \\
\hline $\begin{array}{l}\text { I presently have the skills to include } \\
\text { students with visual impairment } \\
\text { (includes blind) in my } \\
\text { classroom/laboratory. }\end{array}$ & $\begin{array}{c}4 \\
5.1\end{array}$ & $\begin{array}{c}19 \\
24.4\end{array}$ & $\begin{array}{c}23 \\
29.5\end{array}$ & $\begin{array}{c}24 \\
30.8\end{array}$ & $\begin{array}{c}8 \\
10.3\end{array}$ & 3 \\
\hline
\end{tabular}

Note. SA = Strongly Agree; A = Agree; $\mathrm{N}$ = Neutral; $\mathrm{D}$ = Disagree, $\mathrm{SD}=$ Strongly Disagree 
Table 6

Satisfaction and Needs for Support Services

\begin{tabular}{|c|c|c|c|c|c|c|}
\hline Question & $\begin{array}{c}\text { SA } \\
f \\
\%\end{array}$ & $\begin{array}{c}\mathrm{A} \\
f \\
\%\end{array}$ & $\begin{array}{c}\mathrm{N} \\
f \\
\%\end{array}$ & $\begin{array}{l}\mathrm{D} \\
f \\
\%\end{array}$ & $\begin{array}{l}\mathrm{SD} \\
f \\
\%\end{array}$ & Median \\
\hline $\begin{array}{l}\text { In-class support such as peer tutoring } \\
\text { students, paraprofessional, etc. would } \\
\text { be beneficial support in my classroom } \\
\text { with the students with special needs. }\end{array}$ & $\begin{array}{c}30 \\
38.5\end{array}$ & $\begin{array}{c}39 \\
50.0\end{array}$ & $\begin{array}{c}5 \\
6.4\end{array}$ & $\begin{array}{c}3 \\
3.8\end{array}$ & $\begin{array}{c}1 \\
1.3\end{array}$ & 4 \\
\hline $\begin{array}{l}\text { Consultations with special education } \\
\text { teachers, parents etc. would be } \\
\text { beneficial for including students with } \\
\text { disabilities in my classroom. }\end{array}$ & $\begin{array}{c}29 \\
37.2\end{array}$ & $\begin{array}{c}37 \\
47.4\end{array}$ & $\begin{array}{c}10 \\
12.8\end{array}$ & $\begin{array}{c}2 \\
2.6\end{array}$ & $\begin{array}{c}0 \\
0.0\end{array}$ & 4 \\
\hline $\begin{array}{l}\text { Team teaching with special education } \\
\text { teachers/specialists would be beneficial } \\
\text { in including students with special needs } \\
\text { in my classroom. }\end{array}$ & $\begin{array}{c}17 \\
21.8\end{array}$ & $\begin{array}{c}41 \\
52.6\end{array}$ & $\begin{array}{c}14 \\
17.9\end{array}$ & $\begin{array}{c}5 \\
6.4\end{array}$ & $\begin{array}{c}1 \\
1.3\end{array}$ & 4 \\
\hline $\begin{array}{l}\text { The support services I have or am currently } \\
\text { receiving to help me with the inclusion } \\
\text { of students with special needs have } \\
\text { been adequate. }\end{array}$ & $\begin{array}{c}10 \\
12.8\end{array}$ & $\begin{array}{c}29 \\
37.2\end{array}$ & $\begin{array}{c}12 \\
15.4\end{array}$ & $\begin{array}{c}22 \\
28.2\end{array}$ & $\begin{array}{c}5 \\
6.4\end{array}$ & 3.5 \\
\hline $\begin{array}{l}\text { I have received or am receiving adequate } \\
\text { education, training and/or professional } \\
\text { development regarding inclusion and } \\
\text { teaching students with disabilities. }\end{array}$ & $\begin{array}{c}2 \\
2.6\end{array}$ & $\begin{array}{c}16 \\
20.5\end{array}$ & $\begin{array}{c}26 \\
33.3\end{array}$ & $\begin{array}{c}27 \\
34.6\end{array}$ & $\begin{array}{c}7 \\
9.0\end{array}$ & 3 \\
\hline
\end{tabular}

Note. $\mathrm{SA}=$ Strongly Agree; $\mathrm{A}=$ Agree; $\mathrm{N}=$ Neutral; $\mathrm{D}=$ Disagree; $\mathrm{SD}=$ Strongly Disagree

Of those responding, 88.5\% of the teachers expressed that having in-class support such as peer tutoring students, paraprofessional, etc. would be a benefit in their classroom. Teachers also indicated that consultations with parents and special education teachers would be beneficial as well. Nearly $50 \%$ of the respondents were not satisfied with their 
current level or support services and are not receiving adequate training and/or professional development.

Objective Seven: Determine the Willingness of Utah Agriculture Teachers to Participate in Professional Development Regarding Inclusion Activities

Participants were asked to indicate what level of training they would attend in order to more successfully include students with disabilities in their classroom. Table 7 indicates the rankings for each question.

Table 7

Teachers' Willingness to Participate in Professional Development

\begin{tabular}{|c|c|c|c|c|c|c|}
\hline Question & $\begin{array}{c}\text { SA } \\
f \\
\%\end{array}$ & $\begin{array}{l}\text { A } \\
f \\
\%\end{array}$ & $\begin{array}{c}\mathrm{N} \\
f \\
\%\end{array}$ & $\begin{array}{l}\mathrm{D} \\
f \\
\%\end{array}$ & $\begin{array}{l}\text { SD } \\
f \\
\%\end{array}$ & Median \\
\hline $\begin{array}{l}\text { I would attend professional development } \\
\text { workshops dealing with behavior } \\
\text { management. }\end{array}$ & $\begin{array}{c}19 \\
24.4\end{array}$ & $\begin{array}{c}41 \\
52.6\end{array}$ & $\begin{array}{c}14 \\
17.9\end{array}$ & $\begin{array}{c}4 \\
5.1\end{array}$ & $\begin{array}{c}0 \\
0.0\end{array}$ & 4 \\
\hline $\begin{array}{l}\text { I would attend professional development } \\
\text { workshops or activities dealing with } \\
\text { special education techniques. }\end{array}$ & $\begin{array}{c}16 \\
20.5\end{array}$ & $\begin{array}{c}43 \\
55.1\end{array}$ & $\begin{array}{c}17 \\
21.8\end{array}$ & $\begin{array}{c}2 \\
2.6\end{array}$ & $\begin{array}{c}0 \\
0.0\end{array}$ & 4 \\
\hline $\begin{array}{l}\text { I would attend professional development } \\
\text { workshops or activities on how to } \\
\text { collaborate with support service } \\
\text { personnel. }\end{array}$ & $\begin{array}{c}12 \\
15.4\end{array}$ & $\begin{array}{c}40 \\
51.3\end{array}$ & $\begin{array}{c}21 \\
26.9\end{array}$ & $\begin{array}{c}4 \\
5.1\end{array}$ & $\begin{array}{c}1 \\
1.3\end{array}$ & 4 \\
\hline $\begin{array}{l}\text { I would participate in college course work } \\
\text { in Special Education. }\end{array}$ & $\begin{array}{c}10 \\
12.8\end{array}$ & $\begin{array}{c}24 \\
30.8\end{array}$ & $\begin{array}{c}26 \\
33.3\end{array}$ & $\begin{array}{c}13 \\
16.7\end{array}$ & $\begin{array}{c}5 \\
6.4\end{array}$ & 3 \\
\hline
\end{tabular}


The responses indicated that teachers are seeking professional development in regards to behavior management, and special education techniques. They are less likely to participate in workshops in regards to collaboration with support personnel and would not be willing to participate in college course work in Special Education.

Objective Eight: Describe How Students with Special Needs Are Included in the Utah Agriculture Teachers’ Classroom/Laboratories

The participants responded to a series of open ended questions. The first question “Describe how students with special needs are included in the Utah agriculture teachers' classroom/laboratories” received 66 responses that were reviewed. A summary is found in Table 8. See Appendix F for complete comments.

In reviewing the responses, it was noted that many of the teachers included students by encouraging them to participate along with the regular learners. Teachers indicated that the students enjoyed the hands-on opportunities in the agricultural classroom. They prefer to learn in a lab setting and respond to a variety of teaching strategies. A respondent replied, "I have several students in each class with special needs. I have tried to teach in a variety of different ways so that each student has the opportunity to learn.” Many stated that accommodations are made according to their needs. Yet in a shop setting, teachers were adamant about safety and required the exact same testing and safety precautions of their special needs students as they did of their regular learners. A teacher stated "We are told to grade them pass/fail and pass them to stay on the safe side, 
or give them a letter grade if they are passing, but if they fail just give them a pass to be safe.”

Table 8

How Students with Special Needs Are Treated in the Classroom/Laboratory Theme Special needs students are treated the same as regular learners

$N$

Peer tutors and/or aides assist special needs students 19

General accommodations

Modified notes and/or worksheets are provided for disabled students

Variety of teaching strategies used i.e. hands on activities

Collaboration with others

Time accommodations are made

Adjustments to grading expectations

Accommodations made for laboratory assignments

Special equipment and/or technology are used

Teacher needs more skills

Difficult due larger class sizes and lack of assistance

Testing modifications made according to their need

None 
Objective Nine: Summarize the Education/Professional Development

Utah Agriculture Teachers Have Received Regarding Inclusion

Respondents were asked to "Summarize the education/professional development Utah agriculture teachers have received regarding inclusion” and 66 responses were recorded. A summary can be found in Table 9. See Appendix F for complete comments.

\section{Table 9}

Summary of Education and/or Professional Development Regarding Inclusion

\begin{tabular}{lc}
\hline Theme & $N$ \\
\hline $\begin{array}{l}\text { Participated in required university Special Education course or equivalent } \\
\text { Participated in district or school level in-service }\end{array}$ & 30 \\
$\begin{array}{l}\text { Have had no education and/or professional development regarding } \\
\text { inclusion }\end{array}$ & 13 \\
$\begin{array}{l}\text { Have had personal or professional experience with students with } \\
\text { disabilities }\end{array}$ & 9 \\
$\begin{array}{l}\text { Complete specific university special education courses } \\
\text { Have very little education regarding inclusion }\end{array}$ & 7 \\
Attended other professional development workshops & 5
\end{tabular}

It was apparent that relatively little education is given before agriculture teachers enter the teaching field. It was also evident that the Theory of Reasoned Action plays a role in how teachers successfully include students with disabilities in their classrooms. One respondent declared "I think that they just expect us to know how to do it. I had a lot 
of good help from my mother who was a special education teacher,” indicating that with little education teachers are expected to know what to do. Most teachers cannot rely on the knowledge and education of their mothers when including students with special needs in their classroom. It was noted that teachers have participated in limited professional development. Yet many have been involved in district or school level inservice classes.

Objective Ten: List the Support Services Available to the Utah Agriculture Teachers

Participants listed the support services that are currently available to them. Sixtysix respondents indicated the level of support they receive. A summary is found in Table 10.

Table 10

Support Services Available to Utah Agriculture Teachers

\begin{tabular}{ll}
\hline Theme & $N$ \\
\hline Support from Special Education and Resources Teachers/Department & 42
\end{tabular}

Assistance from aides and or paraprofessionals

No support services

Other support (parents, counselors, psychologists, and other professionals)

Participation in IEP conferences and process

Assistance from peer tutors or student teaching assistants

Assistance via equipment and technology 
Respondents indicated receiving positive support from their Special Education and Resources Teachers/Department. One teacher indicated, “I have great special education teachers at my school, they are helpful and willing to answer my questions.” However, some indicated no support at all and that it is perceived that "special education teachers expect you to know already” how and what to do when including students with special needs. It was implied that many teachers go out of their way to seek the assistance they need, collaborating with special education teachers and other support services to make sure the needs of the students are being meet. Overall, it was indicated that teachers do utilize to various degrees the Special Education and Resources Teachers/Department and aides and or paraprofessionals

Objective Eleven: Correlate Selected Demographic Variables with the Analyzed Perceptions of Utah Agriculture Teachers on Inclusion of Students with Disabilities

A stepwise multiple regression analysis was performed in order to identify which survey items accounted for a statistically significant level of variance in the selected demographic variables. The regression was performed at the .05 level of significance. The regression analysis in relationship to gender explained $9.8 \%$ of the variance and indicated that females tended to be willing to attend professional development workshops or activities dealing with behavior management $(p=.008)$. The results of the regression are found in Table 11. 
Table 11

Stepwise Multiple Regression Results of Gender with Survey Items

Variables $\quad$ Beta $\quad t \quad p$

I would attend professional development $\quad-0.314 \quad-2.724 \quad .008 *$ workshops or activities dealing with behavior management.

$* F(1,68)=7.419, p=.008$

$* p<.05$.

The regression analysis indicated that one variable had a statistically significant relationship with gender. The item "I would attend professional development workshops or activities dealing with behavior management” had a negative correlation with gender, $p=.008$. Further analysis indicated that females tended to be willing to attend professional development workshops or activities dealing with behavior management while males tended to be less willing to do so.

A stepwise multiple regression analysis was performed in order to identify which survey items accounted for a statistically significant amount of variance in the age of the respondents. This analysis indicated that $33.6 \%$ of the variance in age was explained by four variables. The variables are listed in Table 12 along with the regression results. 
Table 12

Stepwise Multiple Regression Results of Age with Survey Items

\begin{tabular}{|c|c|c|c|}
\hline Variables & Beta & $t$ & $p$ \\
\hline $\begin{array}{l}\text { I am willing to include students with an emotional } \\
\text { or behavioral disorder in my } \\
\text { classroom/laboratory. }\end{array}$ & -0.534 & -4.406 & $.000 *$ \\
\hline $\begin{array}{l}\text { I presently have the skills to successfully include } \\
\text { students with disabilities in my classroom. }\end{array}$ & 0.295 & 2.768 & $.007^{*}$ \\
\hline $\begin{array}{l}\text { The size of the class needs to be lowered when } \\
\text { students with disabilities are included. }\end{array}$ & -0.255 & -2.422 & $.018 *$ \\
\hline $\begin{array}{l}\text { I would attend professional development } \\
\text { workshops or activities on how to collaborate } \\
\text { with support service personnel. }\end{array}$ & & & \\
\hline
\end{tabular}

$* p<.05$.

The analysis indicated that four variables had statistically significant relationships with the variable age. The first variable to be significant was "I am willing to include students with an emotional or behavioral disorder in my classroom/laboratory,” $p=.000$. Further analysis indicated that younger respondents tended to be willing to include students with an emotional or behavioral disorder in their classrooms/laboratories while older respondents were less likely. The next variable entered into the regression equation was "I presently have the skills to successfully include students with disabilities in my classroom,” $p=.000$. Further analysis showed that the older respondents generally indicated that they presently had the skills to successfully include students with disabilities in their classrooms, while younger teachers indicated otherwise. The third 
variable entered was "The size of the class needs to be lowered when students with disabilities are included,” $p=.007$. The regression analysis showed that older teachers tended to agree that class sizes needed to be lowered when students with disabilities are included while younger teachers agreed to a lesser extent. The final significant variable with age was "I would attend professional development workshops or activities on how to collaborate with support service personnel,” $p=.018$. The younger respondents would generally be more willing to attend professional development workshops or activities on how to collaborate with support service personnel than the older respondents.

A stepwise multiple regression analysis was performed in order to identify which survey items accounted for a statistically significant amount of variance in the size of the community in which the respondents teach. This analysis indicated that $39.5 \%$ of the variance in community size was explained by five variables. The variables are listed in Table 13 along with the regression results.

The analysis indicated that five variables had a statistically significant relationship with the size of the community in which the respondents taught. The first significant variable was "I would participate in college course work in Special Education," $p=.000$. The analysis indicated that the teachers that taught in an urban $(>50,000)$ or suburban $(2,500$ - 49,999) sized communities would be more likely to participate in college course work in Special Education than a rural $(<2,500)$ area teacher.

Table 13 
Stepwise Multiple Regression Results of Community size with Survey Items

\begin{tabular}{|c|c|c|c|}
\hline Variables & Beta & $t$ & $p$ \\
\hline $\begin{array}{l}\text { I would participate in college course work in } \\
\text { Special Education. }\end{array}$ & 0.449 & 4.123 & $.000^{*}$ \\
\hline $\begin{array}{l}\text { There is very little difference in the curriculum } \\
\text { when a student with special needs is included } \\
\text { in the class or group. }\end{array}$ & -0.307 & -3.062 & $.003 *$ \\
\hline $\begin{array}{l}\text { Students with disabilities should be integrated into } \\
\text { general school classes for typically developing } \\
\text { students rather than attending special } \\
\text { education classes. }\end{array}$ & 0.320 & 2.972 & $.004 *$ \\
\hline $\begin{array}{l}\text { I would attend professional development } \\
\text { workshops or activities dealing with special } \\
\text { education techniques. }\end{array}$ & -0.431 & -3.383 & $.001^{*}$ \\
\hline $\begin{array}{l}\text { Consultations with special education teachers, } \\
\text { parents, etc. would be beneficial for } \\
\text { including students with disabilities in my } \\
\text { classroom. }\end{array}$ & 0.321 & 2.883 & $.005^{*}$ \\
\hline \multicolumn{4}{|c|}{${ }^{*} F(5,64)=8.360, p=.000$} \\
\hline
\end{tabular}

$* p<.05$.

The second variable was "There is very little difference in the curriculum when a student with special needs is included in the class or group,” $p=.003$. Further analysis showed that the respondents from the smaller communities tended to agree that there was very little difference in the curriculum for students with special needs, whereas the larger communities disagreed. The third significant variable was "Students with disabilities should be integrated into general school classes for typically developing students rather than attending special education classes,” $p=.004$. This analysis indicated that the 
respondents from the larger communities generally agreed more than the smaller community respondents that students with disabilities should be integrated into general school classes. The fourth variable was "I would attend professional development workshops or activities dealing with special education techniques,” $p=.001$. The analysis of this variable showed that rural respondents would more likely to attend professional development workshops or activities dealing with special education techniques but urban and suburban respondents were not. The final significant variable was "Consultations with special education teachers, parents, etc. would be beneficial for including students with disabilities in my classroom,” $p=.005$. The urban and suburban teachers tended to agree that consultations with special education teachers, parents, etc. would be beneficial for including students with disabilities in their classrooms where the rural teachers tended to disagree.

A stepwise multiple regression analysis was performed in order to identify which survey items accounted for a statistically significant amount of variance in the level of education of the respondents. The regression was performed at the .05 level of significance. This analysis indicated that $36.5 \%$ of the variance in the level of education was explained by four variables. The variables are listed in Table 14 along with the regression results. 
Table 14

Stepwise Multiple Regression Results of Level of Education with Survey Items.

Variables $\quad$ Beta $\quad t \quad p$

In my classroom, teacher/student ratios are

$-0.326$

$-3.092$

$.003 *$

adequate or appropriate for mainstreaming

children with disabilities

I presently have the skills to successfully include

$0.475 \quad 4.089 \quad .000 *$ students with disabilities in my classroom.

A regular classroom setting is probably the best

$.002 *$

placement for which of the following students:

significant level of need.

I presently have the skills to include students with

a learning disability in my

$-0.245$

$-2.203$

$.031^{*}$

classroom/laboratory.

$$
* F(4,64)=9.190, p=.000
$$

$* p<.05$

The analysis indicated that four variables had a statistically significant

relationship with the respondent’s level of education. The first significant variable "In my classroom, teacher/student ratios are adequate or appropriate for mainstreaming children with disabilities,” $p=.003$. Further analysis of this variable indicated that the higher the teacher education level the more they tended to disagree that their classroom teacher/student ratios were adequate while those with less education agreed that their teacher/student ratios were adequate. The second variable "I presently have the skills to successfully include students with disabilities in my classroom,” $\mathrm{p}=.000$. The analysis of this variable indicated that the higher the education the more the more they agreed they 
possessed the skills while those with less education tended to disagree that they possessed the skills to include students with disabilities in their classrooms. The third variable "A regular classroom setting is probably the best placement for which of the following students: significant level of need,” $\mathrm{p}=.002$. Additional analysis indicated that teachers with a lower level of education agreed that placing students with a significant level of need in regular classroom setting is best while those with higher level of education disagreed. The final variable in relationship with the respondent's level of education was "I presently have the skills to include students with a learning disability in my classroom/laboratory,” $p=.031$. The analysis of this variable suggested that the higher the level of education the more they tended to agree that they had the skills to include students with learning disabilities in their classroom/laboratory while those with less education tended to disagree that they did not possess the skills to include students with a learning disability in their classrooms/laboratory.

A stepwise multiple regression analysis was performed in order to identify which survey items accounted for a statistically significant amount of variance as to whether the respondents had participated in an Individual Education Plan (IEP). The regression was performed at the .05 level of significance. This analysis indicated that $15.8 \%$ of the variance in IEP participation was explained by one variable. The variables are listed in Table 15 along with the regression results. 
Table 15

Stepwise Multiple Regression Results of IEP Participation Items

Variables $\quad$ Beta $\quad t \quad p$

The size of class needs to be lowered when

0.397

3.571

$.001 *$

students with disabilities are included.

$$
* F(1,68)=12.750, p=.001
$$

$* p<.05$

The regression analysis indicated that one variable had a statistically significant relationship with IEP participation. The item "The size of class needs to be lowered when students with disabilities are included” had a positive correlation with IEP participation, $p$ $=.001$. Further analysis indicated that if a teacher had participated in the IEP process he/she agreed that class size should be lowered when including students with disabilities. Teachers who had not participated in the IEP process tended to disagree that class size should be lowered when including students with disabilities more than those who had participated in the IEP process.

A stepwise multiple regression analysis was performed in order to identify which survey items accounted for a statistically significant amount of variance in years of teaching experience. The regression was performed at the .05 level of significance. This analysis indicated that $65.6 \%$ of the variance in years of teaching experience was explained by eight variables. The variables are listed in Table 16 along with the regression results. 
Table 16

Stepwise Multiple Regression Results of Years of Teaching Experience

Variables Beta $t$

$p$

I presently have the skills to successfully include

0.595

6.107

$.000 *$

students with disabilities in my classroom.

I am willing to include students with an

$-0.563$

$-5.700$

$.000 *$

emotional or behavioral disorder in my

classroom/laboratory.

The size of the class needs to be lowered when

0.331

4.083

$.000 *$

students with disabilities are included.

I would attend professional development

$-0.349$

$-4.209$

$.000 *$

workshops or activities on how to

collaborate with support service personnel.

I feel secure in managing behavior problems

0.345

3.635

$.001 *$

related to students with disabilities.

I am willing to include students with a learning

$-0.342$

$-3.294$

$.002 *$

disability in my classroom/laboratory.

I am willing to include students with an

0.309

2.650

$.010 *$

intellectual disability in my

classroom/laboratory.

A regular classroom setting is probably the best

$-0.244$

$-2.647$

$.010 *$ placement for which of the following students: Significant level of need.

$$
* F(8,61)=14.522, p=.000
$$

$* p<.05$.

The analysis indicated that eight variables had a statistically significant relationship with the respondent's years of teaching experience. The first variable "I presently have the skills to successfully include students with disabilities in my 
classroom,,$p=.000$. Further analysis indicated that as teachers had more years of teaching experience, were more likely to have the skills that allowed them to successfully include students with disabilities. Teachers with less years of experience indicated that they did not presently posses the skills to successfully include students with disabilities. The second variable, was "I am willing to include students with an emotional or behavioral disorder in my classroom/laboratory,” $p=.000$. Additional analysis of this variable indicated that as the teachers had fewer years of teaching experience, they were more willing to include a student with emotional or behavior disorders. Teachers with more years of teaching experience were less likely to include students with emotional or behavior disorders. The next variable was "The size of the class needs to be lowered when students with disabilities are included,” $p=.000$. Further analysis indicated that the respondents with more teaching experience reported the need for lower class sizes when a student with disabilities was in the class while those with less years of teaching did not. The fourth variable was "I would attend professional development workshops or activities on how to collaborate with support service personnel," $p=.000$. Analysis of the variable indicated that the fewer years of teaching experience the more willing the respondents are to attend professional development workshops or activities on how to collaborate with support service personnel. Teachers with more years of teaching experience indicated less willingness to attend professional development workshops or activities on how to collaborate with support service personnel. The fifth variable to be significant was "I feel secure in managing behavior problems related to students with disabilities,” $p=.001$. In analyzing this variable it was noted that the more years of 
experience the teachers possesses the more secure they felt in managing behavior problems related to students with disabilities. Teachers with less years of teaching experience reported a lower level of security in managing behavior problems related to students with disabilities. The next variable to be significant was "I am willing to include students with a learning disability in my classroom/laboratory,” $p=.002$. Further analysis indicated that the fewer years of teaching experience they have the more willing teachers are to include students with learning disabilities in their classroom teachers with more years of teaching were less likely to include students with a learning disability. The seventh variable of significance stated "I am willing to include students with an intellectual disability in my classroom/laboratory,” $p=.010$. The analysis suggested that the more years of teaching experience, the more the respondents tended to be willing to include students with an intellectual disability in their classrooms. Respondents with fewer years of teaching experience indicated that they were less willing to include students with an intellectual disability in their classrooms. The final variable was "A regular classroom setting is probably the best placement for which of the following students: Significant level of need,” $p=.010$. When analyzing this variable the teachers with fewer years of teaching experience tended to believe that a regular classroom setting was best for student with a significant level of need where teachers with fewer years did not.

A stepwise multiple regression analysis was performed in order to identify which survey items accounted for a statistically significant amount of variance in years of experience teaching students with disabilities. The regression was performed at the .05 
level of significance. This analysis indicated that $61.2 \%$ of the variance in years of experience teaching students with disabilities was explained by seven variables. The variables are listed in Table 17 along with the regression results.

Table 17

Stepwise Multiple Regression Results of Years of Experience Teaching Students with Disabilities

\begin{tabular}{llll}
\hline Variables & Beta & $t$ & $p$
\end{tabular}

I presently have the skills to successfully include students with disabilities in my classroom.

$0.554 \quad 5.288 \quad .000^{*}$

I am willing to include students with an emotional or behavioral disorder in my classroom/laboratory.

$\begin{array}{lll}-0.527 & -5.573 \quad .000 *\end{array}$

I would attend professional development workshops or activities on how to collaborate with support service personnel.

$\begin{array}{lll}-0.353 & -3.959 \quad .000 *\end{array}$

The size of the class needs to be lowered when $\begin{array}{llll}\text { students with disabilities are included. } & 0.230 & 2.579 & .012^{*}\end{array}$

I feel secure in managing behavior problems related to students with disabilities.

$0.381 \quad 3.800 \quad .000^{*}$

A regular classroom setting is probably the best placement for which of the following students: Significant level of need.

Team teaching with special education teachers/specialist would be beneficial in including students with special needs in my $0.202 \quad 2.305 \quad .025^{*}$ classroom.

$$
* F(4,63)=14.801, p=.000
$$

$* p<.05$. 
The analysis indicated that seven variables had a statistically significant relationship with the respondent's years of experience teaching students with disabilities. The first variable "I presently have the skills to successfully include students with disabilities in my classroom” was statistically significant with the dependent variable, $p=.000$. Further analysis indicated that teachers with more years of experience teaching disabled students, they perceived their skill level to be higher than those with less years of experience teaching disable students. The second variable "I am willing to include students with an emotional or behavioral disorder in my classroom/laboratory” was statistically significant in the regression, $p=.000$. Additional analysis of this variable indicated that as teachers had fewer years of teaching students with disabilities, they were more willing to include a student with emotional or behavior disorder. Teachers with more years of experience teaching students with disabilities tended to be less willing to include a student with emotional or behavior disorder. The third variable "I would attend professional development workshops or activities on how to collaborate with support service personnel,” $p=.000$. Analysis of this variable suggested that the fewer years of experience teaching students with disabilities the more willing the respondents were to attend professional development workshops or activities on how to collaborate with support service personnel. The next variable "The size of the class needs to be lowered when students with disabilities are included” had a statistically significant relationship with the dependent variable, $p=.012$. Further analysis indicated that the respondents with more teaching experience of students with disabilities reported the need for lower class sizes when a student with special needs is in the class while teachers with 
less years did not indicate the need for lower class sizes when a student with special needs is in the class. The fifth variable was "I feel secure in managing behavior problems related to students with disabilities,” $p=.000$. In analyzing this variable it was noted that the more years of experience the teachers possessed the more secure they felt in managing behavior problems related to students with disabilities. The next variable “A regular classroom setting is probably the best placement for which of the following students: Significant level of need,” $\mathrm{p}=.016$. When analyzing this variable it was found that teachers with fewer years of teaching students with disabilities tended to believe that a regular classroom setting was best for student with a significant level of need but the teachers with more years of experience teaching students with disabilities tended to disagree that a regular classroom setting was best for students with a significant level of need. The final variable to be significant was “Team teaching with special education teachers/specialist would be beneficial in including students with special needs in my classroom,” $p=.025$. Advanced analysis of this variable indicated that teachers with more experience teaching students with disabilities agreed that team teaching with a special education teachers/specialist would be beneficial.

A stepwise multiple regression analysis was performed in order to identify which survey items accounted for a statistically significant amount of variance in the number of special education courses taken. The regression was performed at the .05 level of significance. The analysis indicated that $17.00 \%$ of the variance was explained in relation to the number of university courses taken but there were no items that were statistically significant. 
A stepwise multiple regression analysis was performed in order to identify which survey items accounted for a statistically significant amount of variance in the number of professional development workshops attended. The regression was performed at the .05 level of significance. The analysis did indicate a $21.50 \%$ of variance to be explained for the number of professional development workshops attended. There were four variables explained. The variables are listed in Table 18 along with the regression results.

\section{Table 18}

Stepwise Multiple Regression Results of Number of Professional Development Workshops Attended

\begin{tabular}{|c|c|c|c|}
\hline Variables & Beta & $t$ & $p$ \\
\hline I understand the concept of inclusion. & 0.295 & 2.331 & $.023^{*}$ \\
\hline $\begin{array}{l}\text { I presently have the skills to successfully include } \\
\text { students with disabilities in my classroom. }\end{array}$ & 0.475 & 4.089 & $.000^{*}$ \\
\hline $\begin{array}{l}\text { A regular classroom setting is probably the best } \\
\text { placement for which of the following } \\
\text { students: significant level of need. }\end{array}$ & -0.347 & -3.169 & $.002 *$ \\
\hline $\begin{array}{l}\text { I presently have the skills to include students with } \\
\text { a learning disability in my } \\
\text { classroom/laboratory. }\end{array}$ & -0.245 & -2.203 & $.031 *$ \\
\hline \multicolumn{4}{|c|}{$* F(4,64)=9.190, p=.000$} \\
\hline
\end{tabular}

$* p<.05$.

The analysis indicated four variables were statistically significant in relationship to the number of professional development workshops attended. The first statistically 
significant variable was "I understand the concept of inclusion," $p=.023$. Further analysis indicated that teachers who attended more professional development workshops tended to understand inclusion more than those who attended less professional development workshops. The second significant variable was "I presently have the skills to successfully include students with disabilities in my classroom,” $p=.000$. Analysis of this variable indicated that teachers that had attended more professional development workshops indicated that they had the skills to successfully include students with disabilities in their classrooms. The next significant variable "A regular classroom setting is probably the best placement for which of the following students: significant level of need,” $p=.002$. This variable suggested that the less professional development workshops a teacher had attended, the more they agreed that students with a significant level of need would be best served when placed in a regular classroom setting. Teachers that had attended more professional development workshops were more likely to disagree that students with a significant level of need would be best served when placed in a regular classroom setting. The final variable "I presently have the skills to include students with a learning disability in my classroom/laboratory,” $\mathrm{p}=.031$. Further analysis indicated that the less professional development workshops a teacher had attended, the more they agreed that they had the skills to included students with learning disabilities in their classrooms whereas the teachers that had attended more professional development workshops disagreed that they had the skills to include students with learning disabilities in their classrooms. 


\section{CHAPTER V \\ CONCLUSIONS AND RECOMMENDATIONS}

\section{Summary}

Nearly $90 \%$ of the teachers surveyed indicated that they understand the concept of inclusion/integration and $76.9 \%$ of teachers were in favor of including students with disabilities in their classrooms and laboratories. Over $80 \%$ have had a positive experience teaching students with disabilities. Many of the respondents only agreed or were neutral when indicating their skill level to successfully include students with disabilities in their classroom. Similar results were reflected in Center and Ward's (1987) study in which teachers were generally positive about integrating students with disabilities yet lacked confidence in their abilities.

Overall, the teachers in this study had the will to include the majority of students with specific disabilities yet lacked the skill to do so successfully. Willingness varied based upon the type of disability. As an example of this disparity, $87 \%$ of teachers indicated willingness to include students with a hearing impairment, yet only $46 \%$ of them perceived that they possessed the skills to successfully include these students in their classrooms and laboratories.

Cooper et al. (2002) noted that there is a great deal of shop and laboratory experience built into the agricultural education curriculum. In a shop or laboratory setting, the most pressing concern with all students is safety. When students with special 
needs are included in classes this concern should be heightened. The results of this study suggest that the type of disability a student has influences the teacher's willingness and perceived skill level in including these students. Similarly, Ward et al. (1994) found that attitudes are greatly affected by the nature of the disability and/or educational problems that exist.

Nearly all teachers in this study agreed or strongly agreed that the regular classroom setting was the best placement for students with a mild level of need, yet only $17 \%$ agreed and none strongly agreed that it was the best setting for students with a significant level of need. An interesting finding in this area was that teachers with fewer years of experience were more likely to agree that students with a significant level of need would be best served in a regular classroom setting when compared to teachers with more experience. Similar trends were found throughout the study, including a higher level of willingness to include students with behavioral and emotional disorders and students with multiple disabilities amongst teachers with fewer years of experience.

The majority of teachers in the study reported that they are not receiving adequate support, education, or professional development regarding the inclusion and teaching of students with disabilities. Some did, however, indicate that in-class support, consultations with parents and special education teachers, and team teaching would be very beneficial for providing a successful experience for a student with disabilities and the teachers involved. More than three-fourths of teachers agreed that they would be willing to attend professional development workshops to improve their abilities to include students, and 
$66 \%$ reported that they would like professional development workshops on how to collaborate with support services.

\section{Purpose and Objectives of the Study}

The purpose of this study was to assess Utah agricultural education teachers' attitudes toward including students with disabilities in their classrooms and laboratories and to determine their perceived ability to include students with disabilities in their classrooms and laboratories. The results of this study will help teacher educators and state leaders provide effective professional development opportunities based on current perceptions, abilities and needs of including students with disabilities in agricultural classrooms and laboratories.

To achieve this purpose, the following objectives served as guidelines:

1. Describe the demographic profile of Utah secondary agriculture teachers;

2. Determine the perceived attitudes and ability of Utah agriculture teachers concerning the inclusion of students with disabilities;

3. Determine the perceived security level of Utah agriculture teachers concerning the inclusion of students with disabilities;

4. Determine the willingness of Utah agriculture teachers to include students with specific disabilities;

5. Determine the skill set of Utah agriculture teachers to include students with specific disabilities; 
6. Determine the satisfaction level of Utah agriculture teachers with available support services;

7. Determine the willingness of Utah agriculture teachers to participate in professional development regarding inclusion activities;

8. Describe how students with special needs are included in the Utah agriculture teachers' classroom/laboratories;

9. Summarize the education/professional development Utah agriculture teachers have received regarding inclusion;

10. List the support services available to the Utah agriculture teachers; and

11. Correlate selected demographic variables with the analyzed perceptions of Utah agriculture teacher on inclusion of students with disabilities.

\section{Conclusions and Discussion}

Based upon the findings of the study, the following conclusions were drawn. Teachers did indicate that they understood inclusion. However, some teachers suggested they currently had no special needs students in their classrooms, although they did respond that they currently had students in their classes who had an IEP. This disconnect is a concern and may be reflected in the perception of their beliefs and not reality of what inclusion really is. The perception by a majority of teachers is that education regarding inclusion is limited. Based on these findings, Utah agriculture teachers need additional assistance, education and professional development regarding inclusion of students with 
special needs. If teachers are required to successfully include students with special needs they need to be prepared.

As teachers' willingness varied according to the type of disability, the question arises regarding the adequacy of the accommodations that students with particular disabilities are receiving. The assumption was made that the less experience a teacher has with a specific disability the less willing they are to include that student. Overall, some reservations that were indicated by respondents could reflect the lack of confidence in having special needs students in laboratory settings.

The respondents who tended to agree they were skilled in teaching students with disabilities were those teachers with more years of experience, yet these experienced teachers were more particular as to the type of disability they were willing to include, and were less willing to accept assistance from others. This may, however, indicate that teachers with more years of experience have become stagnate in their teaching approach, have had less exposure to students with special needs, or are less willing to adapt or change their teaching strategies.

Teachers with fewer years of experience appeared to be more open to the type of disability they would include in their classroom or laboratory. This relationship could potentially be explained by idealistic expectations as novice teachers enter the profession, more adequate preparation or interaction with students with disabilities, or a lack of experience in teaching students with these types of challenges. Regardless of the explanation, as supported by the Fishbein and Ajzen theory (1975), a relationship was found in this study between experience and beliefs. 
The level of support that teachers were receiving overall seemed inadequate yet interestingly, a respondent answered that he/she receives zero support and that he/she prefers this method. This gives the perception that if they do not ask for support it will appear that they know what they are doing and are successful at including students with disabilities. Based upon the results of the current study, and supported by the literature (Dickens-Smith, 1995), leaders in agricultural education and special education should seriously consider professional development opportunities targeted at providing teachers with the skills and ability to successfully include students with special needs in their classrooms and laboratories.

The concern arises as to whether we truly are practicing inclusion. Are we truly providing a quality education and experience for students with disabilities?

\section{Recommendations and Implications}

Teachers should be properly trained and attitudes assessed on both a national and regional level regarding inclusion of students with special needs in agriculture classes. The teachers in this study reported willingness to include students with special needs, but indicated a lack of confidence in their skills to successfully do so. Based on these findings, questions arise regarding the adequacy of accommodations students with special needs are receiving in agricultural education classrooms. While agricultural education’s variety of teaching methods, authentic instruction, and hands-on approach have the potential to benefit students with disabilities, some of the reservations displayed by the respondents could reflect the lack of confidence in having a special needs student in a 
laboratory setting. Discussions should be held in collaboration with special education professionals regarding the inclusion of students with severe disabilities in laboratory settings. To increase teachers' abilities, specific in-service programs and professional development should be developed and implemented, addressing the needs of specific disabilities in specific agricultural education classroom and laboratory settings. Future curriculum projects should enhance the ability of teachers to accommodate students with disabilities

\section{Recommendations for Further Study}

Based upon the findings of this research, it is suggested that:

1. Further research be conducted to assess specifically the needs and safety risks of agriculture teachers teaching students with special needs in shop/laboratory settings; and,

2. Qualitative research be conducted to distinguish between teachers' perceived abilities and attitudes toward including students with disabilities and actual behavior related to inclusion.

\section{Final Statement}

Center and Ward (1987) stated, “Once education realizes that, by raising teacher competencies to accommodate disabled children in the classroom, the education of all children will be improved and attitudes concerning the effectiveness of mainstreaming should become increasingly more positive” (p. 55). It has become the teacher’s 
responsibility to provide a fair and accommodating education for all students.

According to this study teachers have the will to include students with disabilities, yet their perception that they possess the necessary skills to do so successfully is low. This issue needs to be addressed in order that every student has the opportunity to succeed in agricultural education classrooms and laboratories. 


\section{REFERENCES}

Ajzen, I., \& Fishbein, M. (1980). Understanding attitudes and predicting social behaviors. Englewood Cliffs, NJ: Prentice Hall.

Avramidis, E., \& Norwich, B. (2002). Teachers' attitude towards integration/inclusion: A review of the literature. European Journal of Special Needs Education, 17(2), 129-147.

Berryman, J. D. (1989). Attitudes of the public toward education mainstreaming. Remedial and Special Education, 10, 44-49.

Brandon, D. P., \& Ncube, M. M. (2006). Botswana’s agriculture teachers’ attitudes towards inclusion of students with physical disabilities in mainstream classes. The Negro Educational Review, 57(3-4), 215-227.

Center, Y., \& Ward, J. (1987). Teachers’ attitudes towards the integration of disabled children into regular schools. Exceptional Children, 34, 41-56.

Cooper, K., Bocksnick, J., \& Frick, M. (2002). Trends in working with special needs students. The Agricultural Education Magazine, 75(3), 6-7.

Dickens-Smith, M. (1995). The effect of inclusion training on teacher attitude towards inclusion. (ERIC Document Reproduction Service No. ED381486)

Dillman, D. A. (2000). Mail and internet surveys: The tailored design method ( $2^{\text {nd }}$ ed.). New York: Wiley.

Dormody, T. J., Seevers, B. S., Andreasen, R. J., \& VanLeeuwen, D. (2006). Challenges experienced by New Mexico agricultural education teachers including special needs students. Journal of Agricultural Education, 47(2), 93-105. 
Elbert, C. D., \& Baggett, C.D. (2003). Teacher competence for working with disabled students as perceived by secondary level agricultural instructors in Pennsylvania. Journal of Agricultural Education, 44(1), 105-114.

Fishbein, M., \& Ajzen, I. (1975). Belief, attitude, intention, and behavior: An introduction to theory and research. Reading, Massachusetts: Addison-Wesley.

Gall, M. D., Borg, W. R., \& Gall, J. P. (1996). Educational Research: An introduction (6 ${ }^{\text {th }}$ ed.). White Plains, NY: Longman.

Gemmell-Crosby, S., \& Hanzlik, J. (1994). Preschool teachers’ perceptions of including children with disabilities. Education and Training in Mental Retardation and Developmental Disabilities, 29(4), 279-90.

Gent, P. J., \& Mulhauser, M. B. (1988). Public integration of students with severe handicaps: Where it's been, where it's going, and how it's getting there. Journal of the Association for Persons with Severe Handicaps, 13(3), 188-196.

Guralnick, M. J. (1982). Mainstreaming young handicapped children: A public policy and ecological systems analysis. In B. Spodek (Ed.), Handbook of research on early childhood education (pp. 456-500). New York: The Free Press/MacMillan.

Hanline, M. F. (1985). Integrating disabled children. Young Children, 40(2), 45-48.

Hudson, F., Graham, S., \& Warner, M. (1979). Mainstreaming: An examination of the attitudes and needs of regular classroom teachers. Learning Disability Quarterly, 3, 58-62.

Linder, J. R., Murphy, T. H., \& Briers, G. E. (2001). Handling nonresponse in social science research. Journal of Agricultural Education, 42(4), 43-53. 
Mittler, P. (2003). Building bridges between special and mainstream services. Inclusions: Theory and Practice. Enabling Education Network. Retrieved August 17, 2008, from http://www.eenet.org.uk/theory_practice/build_bridges.shtml

Odom, S. L., \& McEvoy, M. A. (1990). Mainstreaming at the preschool level: Potential barriers and tasks for the field. Topics in Early Childhood Special Education, 10(2), 48-61.

Patton, M. Q. (2002). Qualitative research and evaluation methods. Thousand Oaks, CA: Sage Publications.

Phillips, W. L., Allred, K., Bruelle, A., \& Shank, K. (1990). The will and skill of regular education. Teacher Education and Special Education, 13, 182-186.

Pivik, J., McComas, J., \& Laflamme, M. (2002). Barriers and facilitators to inclusive education as reported by students with physical disabilities and their parents. Exceptional Children, 69, 91-107.

Public Law 101-476. (1990). Federal Register, 54, 35210-35271.

Public Law 94-142. (1975). Federal Register, 42, 42474-42518.

Ricketts, J., \& Duncan, D. (2005). A teaching and learning needs assessment for Georgia agriculture teachers. The Agricultural Education Magazine, 78(1), 22-24.

Shotel, J. R., Iano, R. P., \& McGettingan, J. F. (1972). Teacher attitudes associated with the integration of handicapped children. Exceptional Children, 38, 677-683.

Slavin, L., Leavey, M., \& Madden, N. (1984). Combining cooperative learning and individualized instruction. Elementary School Journal, 84, 408-422. 
Sorenson, T. J., Tarpley, R. S., \& Warnick, B. K. (2005). Inservice needs of Utah agriculture teachers. Proceedings of the $24^{\text {th }}$ Annual Western Region Agricultural Education Conference, Prescott, AZ.

Stainback, S., \& Stainback, W., \& Forest, M. (Eds.). (1989). Educating all students in the mainstream of regular education. Baltimore: Paul H. Brookes.

U.S. Department of Education. (1994). Final report to congress: Summary and recommendations the furture of Perkins. Washington, DC: U.S. Department of Education.

U. S. Department of Education Office of Special Education and Rehabilitative Services Office of Special Education Programs. (2008). Report of children with disabilities receiving special education part $b$, individuals with disabilities education amended: Utah. Retrieved November 11, 2008, from http://www.schools.utah.gov/sars/data/07-08/0708ccount.pdf

Utah State Office of Education. (2008). Disability information. Retrieved October 8, 2008, from http://www.schools.utah.gov/sars/inforesource/disabilities.htm

Ward, J., Center, Y., \& Bochner, S. (1994). A question of attitudes: Integrating children with disabilities into regular classrooms? British Journal of Special Education, 21, 34-39.

Werts, M. G., Wolery, M., Snyder, E. D., \& Caldwell, N. K. (1996). Teachers’ perceptions of the supports critical to the success of inclusion programs. Association for Persons with Severe Handicaps, 21(1), 9-21. 
Williams, R. J., \& Algozzine, B. (1979). Teachers’ attitudes toward mainstreaming. Elementary Journal, 80(2), 63-67. 
APPENDICES 
Appendix A: The Perceptions of Agriculture Teachers on Including Students with Disabilities 
The Perceptions of Agriculture Teachers on Including Students with Disabilities

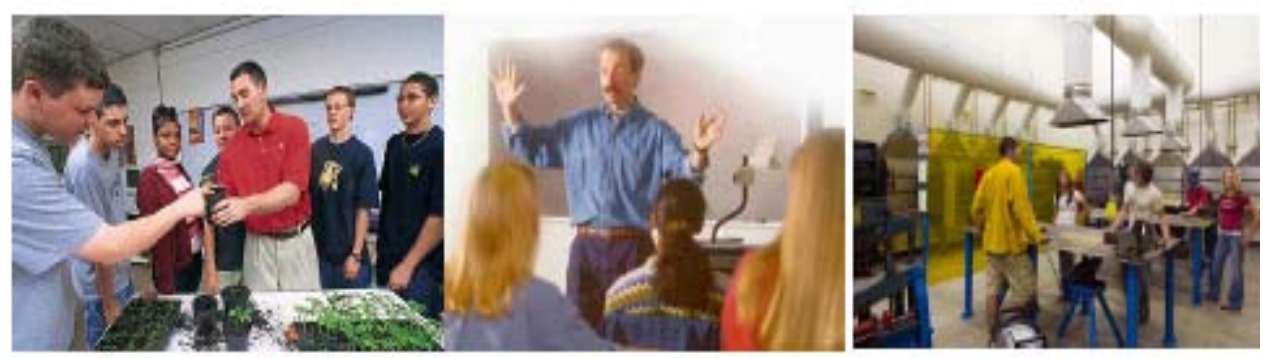

\section{Agricultural Systems Technology and Education \\ Utah State University}




\section{Survey Directions}

This survey seeks to identify Agriculture Education Teachers' attitude toward classroom inclusion students with disabilities and to determine their perceived ability to include students with disabilities in their classroom and laboratories. As a result of the study, teacher needs regarding inclusion will be identified. This model will then be used to create appropriate professional development activities for agriculture teachers.

\section{Section I: Personal and Professional Characteristics:}

Please respond to the following personal and professional characteristics questions by placing an $\mathrm{X}$ on the line that best describes the correct answer or fill in the blank provided.

Section II: Attitudes and Abilities toward inclusion:

Please specify on the designated scale to what degree you feel the statements are true by circling the number that corresponds to your choice.

Section III: Teachers' satisfaction with support services, and education:

Please specify on the designated scale to what degree you feel the statements are true by circling the number that corresponds to your choice

Section IV: Comments regarding inclusion, education and training, and support services:

Please provide any comments you may have to the question listed. If you need additional space utilize the back page of section IV.

\section{Deadline for Completion}

Please complete and return the survey using the self-addressed stamped envelope provided in the survey packet. Please return the survey no later than November 10, 2008.

\section{Contact Information}

If you have any questions concerning this survey, please feel free to contact Dr. Brian Warnick at 435-797-0378 or brian.warnick@usu.edu.

Thank you for completing this survey we understand your time is extremely valuable, and we appreciate your participation. 


\section{Start Here \\ Section I: Personal and Professional Characteristics}

Directions: Please respond to the following personal and professional characteristics questions by placing an $\mathrm{X}$ on the line or by providing the information that best describes the correct answer.

\begin{tabular}{|c|c|}
\hline 1. Gender: & Female: _____ \\
\hline 2. Age: & \\
\hline $\begin{array}{l}\text { 3. The community in which you } \\
\text { teach } \\
\text { would be considered: }\end{array}$ & $\begin{array}{ccc}\text { Rural: } & \text { Suburban: ___ Urban: } \\
(<2,500) & (2,500-49,999) & (>50,000)\end{array}$ \\
\hline 4. Highest Level of Education: & \begin{tabular}{|ll} 
Bachelors Degree: _-_- & Bachelors +: \\
Masters Degree: & Masters +:
\end{tabular} \\
\hline $\begin{array}{l}\text { 5. I have participated in an IEP } \\
\text { process. }\end{array}$ & Yes: ____ No: ___ \\
\hline 6. Years of teaching experience: & \\
\hline $\begin{array}{l}\text { 7. Years of experience teaching } \\
\text { children with disabilities: }\end{array}$ & \\
\hline $\begin{array}{l}\text { 8. Number of special education } \\
\text { courses taken: }\end{array}$ & $\begin{array}{l}\text { University Courses } \\
\text { _-__-_ Professional Development Workshops }\end{array}$ \\
\hline
\end{tabular}

9. Please select all of the related service providers that you have worked with: Occupational Therapist Physical Therapist Speech Language Pathologist Other (psychologist, nurse, etc.) Special Education Teacher None of the above 


\section{Section II: Attitudes and Abilities towards inclusions}

Directions: Please specify on the designated scale to what degree you feel the statements are true about your perspective of inclusion.

Inclusion Perspective: Please indicate your skill level and understanding of including students with special needs in your classroom/laboratory:

1. I understand the concept of inclusion/integration.

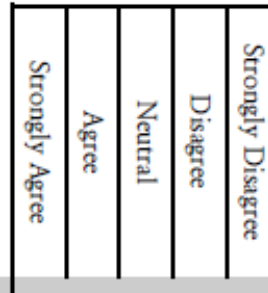

2. Students with disabilities should be integrated into general school classes for typically developing students rather than attending special education classes.

3. The size of the class needs to be lowered when students with disabilities are included.

$\begin{array}{lllll}5 & 4 & 3 & 2 & 1\end{array}$

4. I presently have the skills to successfully include students with disabilities in my classroom.

5. The inclusion of students with special needs into regular classes will take much of the teacher's time and attention from typically developing students.

6. I am in favor of including students with disabilities in my class. 


\section{Section II continued: Attitudes and Abilities towards inclusions}

Abilities: Please indicate your level of security regarding your ability to include students with disabilities in your classroom/laboratory.

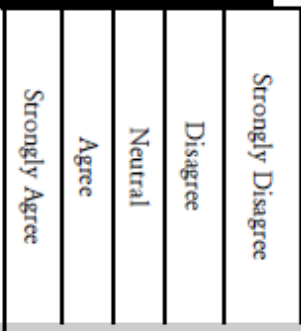

7. I feel secure in my abilities to adapt materials/curriculum for students with disabilities.

8. I feel secure in managing behavior problems related to students with disabilities.

9. I feel I can create a safe environment in my classroom/laboratory for all students when including students with disabilities.

10. I feel secure in my abilities to work with parents of students with disabilities.

\begin{tabular}{|c|c|c|c|c|c|}
\hline 11. I feel secure in my abilities to interpret assessment results. & 5 & 4 & 3 & 2 & 1 \\
\hline $\begin{array}{l}\text { 12. I feel comfortable participating in Individual Education Plan (IEP) } \\
\text { Conferences. }\end{array}$ & 5 & 4 & 3 & 2 & 1 \\
\hline \multicolumn{6}{|l|}{$\begin{array}{l}\text { 13. A regular classroom setting is probably the best placement for which of } \\
\text { the following students: }\end{array}$} \\
\hline A. Mild level of need & 5 & 4 & 3 & & 1 \\
\hline B. Moderate level of need & 5 & 4 & 3 & 2 & 1 \\
\hline C. Significant level of need & & & 3 & & \\
\hline 14. In my classroom, teacher/student ratios are adequate or appropriate for & 5 & 4 & 3 & 2 & 1 \\
\hline 15. There is very little difference in the curriculum when a student with & 5 & 4 & 3 & 2 & 1 \\
\hline 16. The extra paperwork and time needed for students with disabilities & 5 & 4 & 3 & 2 & 1 \\
\hline 17. My experience in teaching students with disabilities has been mostly & 5 & 4 & 3 & & 1 \\
\hline
\end{tabular}




\section{Section II continued: Definitions}

Definitions: Please use the following information to complete the remainder of section II.

\begin{tabular}{|c|c|}
\hline Autism & $\begin{array}{l}\text { A developmental disability significantly affecting verbal and nonverbal com- } \\
\text { munication and social interaction that adversely affects the student's educa- } \\
\text { tional performance. Other characteristics often associated with autism are } \\
\text { engagement in repetitive activities, and stereotyped movements, resistance } \\
\text { to environmental change or change in daily routine and unusual responses } \\
\text { to sensory experiences. }\end{array}$ \\
\hline $\begin{array}{l}\text { Emotional or Behavioral } \\
\text { Disorders }\end{array}$ & $\begin{array}{l}\text { "Emotional disturbance" is used as a generic term to cover two types of be- } \\
\text { havior difficulties which are not mutually exclusive but which adversely af- } \\
\text { fect educational performance: (1) Externalizing refer to behavior that are } \\
\text { directed outwardly towards the social environment and usually involves be- } \\
\text { havioral excesses, and (2) Internalizing refers to a class of behavior prob- } \\
\text { lems that are directed inwardly and often involves behavior deficits. }\end{array}$ \\
\hline $\begin{array}{l}\text { Hearing } \\
\text { Impairment } \\
\text { Deafness }\end{array}$ & $\begin{array}{l}\text { Deafness is a hearing impairment so severe that the student is impaired in } \\
\text { processing linguistic information through hearing, with or without amplifica- } \\
\text { tion. }\end{array}$ \\
\hline Intellectual Disability & $\begin{array}{l}\text { A student who demonstrates sub-average intellectual functioning concur- } \\
\text { rently with deficits in adaptive behavior. Students with intellectual disabili- } \\
\text { ties are those individuals who exhibit cognitive and adaptive behavior defi- } \\
\text { cits that are likely to be life-long disabilities which can interfere with inde- } \\
\text { pendent living. (ID) }\end{array}$ \\
\hline Learning Disability & $\begin{array}{l}\text { A disorder in one of the basic psychological processes involved in under- } \\
\text { standing or in using language, spoken or written, which may manifest itself } \\
\text { in an impaired ability to listen, think, speak, write, spell, or to do mathe- } \\
\text { matical calculations. The term includes such conditions as perceptual dis- } \\
\text { abilities, brain injury, minimal brain dysfunction, dyslexia and developmen- } \\
\text { tal aphasia. }\end{array}$ \\
\hline $\begin{array}{l}\text { Multiple } \\
\text { Disabilities }\end{array}$ & $\begin{array}{l}\text { Combination of two or more disabilities which causes severe educa- } \\
\text { tional deficit (such as intellectual disability-blindness; intellectual } \\
\text { disability-orthopedic impairment, etc.). }\end{array}$ \\
\hline Orthopedic Impairment & $\begin{array}{l}\text { A severe orthopedic impairment, the term includes impairments caused by } \\
\text { congenital anomaly (e.g., clubfoot, absence of some member, etc.), impair- } \\
\text { ment caused by disease (e.g. Poliomyelitis, bone tuberculosis, etc.), and } \\
\text { impairments from other causes (e.g. cerebral palsy, amputations, and frac- } \\
\text { tures or burns that cause contractures) }\end{array}$ \\
\hline Visual Impairment & $\begin{array}{l}\text { Impairment in vision that, even with correction, the term includes both par- } \\
\text { tial sight and blindness. }\end{array}$ \\
\hline
\end{tabular}


Section II continued: Attitudes and Abilities towards inclusions

Disability Level: Please indicate your level of willingness to include the following students in your class:

18. I am willing to include students with autism in my classroom/laboratory.

19. I am willing to include students with an emotional or behavioral disorder in my classroom/laboratory.

20. I am willing to include students with a hearing impairment/deafness in my classroom/laboratory.

21. I am willing to include students with an intellectual disability in my classroom/laboratory.

22. I am willing to include students with a learning disability in my classroom/laboratory.

23. I am willing to include students with multiple disabilities in my classroom/laboratory.

24. I am willing to include students with an orthopedic impairment in my classroom/laboratory.

25. I am willing to include students with visual impairment (includes blind) in my classroom/laboratory. 


\section{Section II continued: Attitudes and Abilities towards inclusions}

Skill Level: Please indicate your skill level to successfully include the following students in your class:

26. I presently have the skills to include students with autism in my classroom/laboratory.

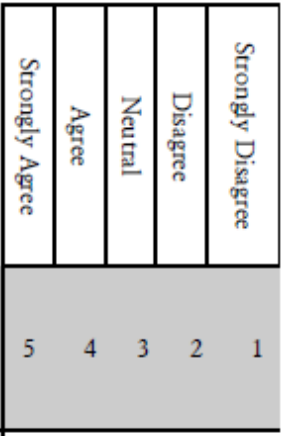

27. I presently have the skills to include students with emotional or behavioral disorder in my classroom/laboratory.

28. I presently have the skills to include students with a hearing impairment/deafness in my classroom/laboratory.

29. I presently have the skills to include students with an intellectual disability in my classroom/laboratory.

30. I presently have the skills to include students with a learning disability in my classroom/laboratory.

31. I presently have the skills to include students with multiple disabilities in my classroom/laboratory.

32. I presently have the skills to include students with an orthopedic impairment in my classroom/laboratory.

33. I presently have the skills to include students with visual impairment (includes blind) in my classroom/laboratory. 


\section{Section III: Teachers' satisfaction with support services, and education}

Directions: Please indicate to what degree you feel the statements are true about supports services you receive or could use more successfully include students with special needs in your classroom.

1. The support services I have or am currently receiving to help me with the inclusion of students with special needs have been adequate.

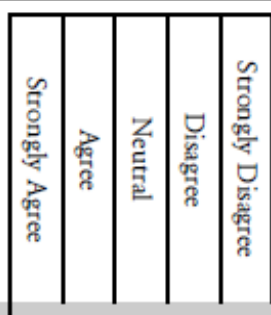
the inclusion of students with special needs have been adequate.

2. I have received or am receiving adequate education, training and/or professional development regarding inclusion and teaching students with disabilities.

3. Consultations with special education teachers, parents etc. would be beneficial for including students with disabilities in my classroom.

4. In-class support such a peer-tutoring students, paraprofessional, etc. would be beneficial support in my classroom with student with special needs.

5. Team teaching with special education teachers/specialists would be beneficial in including students with special needs in my classroom. 


\section{Section III continued: Teachers' satisfaction with support services, and education}

Directions: Please indicate to what degree you feel the statements are true about supports services you receive or could use more successfully include students with special needs in your classroom.

Successful Inclusion: Please indicate what you would attend in order to more successfully include students with disabilities in your class:

6. I would attend professional development workshops or activities dealing with special education techniques.

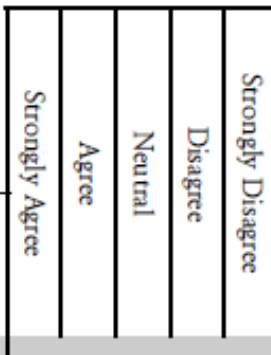

7. I would attend professional development workshops or activities dealing with behavior management.

8. I would attend professional development workshops or activities on how to collaborate with support service personnel.

9. I would participate in college course work in Special Education. 


\section{Section IV: Comments regarding inclusion, education, and train- ing, and support services}

Directions: Please provide any comments you may have to the items listed. If you need additional space utilize the back of this page.

1. Describe how students with special needs are included in your class/laboratory.

2. What education/professional development regarding inclusion have you received?

3. What support services are currently available to you?

This concludes the questionnaire. Thank you for your responses! Please return the survey by November 10, 2008

Thank You! 
Appendix B: Pre-Notice Letter 
September 19, 2008

Dear

A few days from now you will receive a packet in the mail requesting your participation in a very important research project being conducted by the Agriculture Education Department at Utah State University. The questionnaire will ask questions about Agriculture Teacher Perceptions and Professional Development Regarding Inclusion of Students with Disabilities in an attempt to determine the attitudes and aptitudes of Utah agriculture teachers toward inclusion. We will also be collecting demographic information about the agriculture teachers' participating in the research.

Your packet will include all of the information needed to complete the questionnaire. All responses will be confidential. Please complete all parts of the survey and follow the procedures outline in your letter of information. Completing the survey should take less than 15 minutes.

I am mailing you now because many people like to know in advance that they will be contacted. Thank you for your time and consideration. It is only with the generous help of professionals like you that research can benefit Agricultural Educators.

Sincerely, Monica Giffing

Graduate Researcher

Brian Warnick

Assistant Professor 
Appendix C: Cover Letter and Informed Consent Document 
October 10, 2008

Dear

We are writing to ask for your help in a study to determine Utah Agriculture Education Teachers perception of inclusion, your personal abilities to include children with disabilities and your success of inclusion in their classrooms. The information collected from the study will help to identify the perception and needs of the current Utah Agriculture Education Teachers in regards to inclusion of children with disabilities in their classrooms. As an Agriculture teacher and a beneficiary of the results, you have been selected to participate in the study.

Your responses, together with others, will be combined and used for statistical summaries only. Your participation in this study is voluntary and you may refuse to answer any question. The answers you provide will be kept confidential to the extent permitted by law. A code number has been assigned to your survey, once you have responded and returned your questionnaire in the provided pre-stamped envelope you will be removed from the mailing list, and your responses will be destroyed once the data has been tallied. There are no anticipated risks to you as a participant in this project; nor are there any direct benefits.

Your participation is extremely valued. If for some reason you do not wish to participate in this study, or if you do not teach agriculture, please let us know by responding to Brian.Warnick@usu.edu and you will be removed from the follow up list.

If you have any questions or comments concerning this study, we would be happy to talk with you. Please feel free to contact Brian Warnick anytime at 435-797-0378 or Brian.Warnick@usu.edu.

Sincerely,

Monica Giffing

Brian Warnick

Graduate Researcher

Assistant Professor 
Appendix D: First Reminder Post Card Mailing 
Dear

In the last couple of weeks, a questionnaire regarding Utah Agriculture Education Teachers perception of inclusion, personal abilities to include children with disabilities and success of inclusion in the classroom was sent to you.

If you have already responded please accept our sincere appreciation. If not please do so today. We are especially grateful for your help because it is only by hearing from everyone that we can accurately determine the results.

If you have any questions or comments concerning this study, we would be happy to talk with you. Please feel free to contact Dr. Brian Warnick anytime by telephone at 435-7970378 or via email brian.warnick@usu.edu.

Thank you again for your help in this important study.

Sincerely,

Monica Giffing

Graduate Researcher
Brian Warnick

Assistant Professor 
Appendix E: Final Reminder Letter 
Dear

We are completing our research study concerning Utah Agriculture Education Teachers perception of inclusion, your personal abilities to include students with disabilities and the success of inclusion in the classroom.

WE NEED A FEW MORE SURVEYS TO REACH OUR GOAL!

If you have already completed and returned the questionnaire, please accept our sincere thanks. If not please take a moment to do so today! Just in case you have misplaced the previous sent information we have included another questionnaire and letter of information for your answering pleasure.

We are especially grateful for your help because it is only by hearing from everyone that we can accurately determine the results. If you have any questions or comments concerning this study, we would be happy to talk with you. Please feel free to contact Dr. Brian Warnick anytime by telephone at 435-797-0378 or via email brian.warnick@usu.edu.

Thank you again for your help in this important study.

Monica Giffing

USU ASTE Graduate Assistant 
Appendix F: Responses to Open Ended Questions 


\section{Describe how students with special needs are included in your classroom/laboratory.}

Verbatim comments (spelling and grammar errors included)

- Placed in groups with peer tutors.

- I currently have a student with a hearing impairment Our school district has placed a microphone and voice enhancement in my classroom as well was training for hearing inclusion.

- They are placed in my class with no notice of their needs. I have learned to watch for distinguishing characteristics.

- I modify the labs to make them available to all.

- They love to feed the cows and calves.

- They are usually the students wanting to do the most hands on stuff. They are good to have around for the other kids as well.

- First, with the help of aids - student or adult.

- They have peer tutors to help them, Worksheets are simplified to their level, Peers are usually willing to include and help them.

- I have several students with autism in my class some have done well but some have not. The problem is the college level course material and relationship some have had working with animals.

- They are included like all other students and participate in the same activities but with needed special adaptations.

- Attend class and participate in normal classroom activities.

- I usually pair them up with other students to perform the hands on tasks we do in class.

- Treat them the same - provide accommodations.

- Most are coached by paraprofessionals lessons quantity and length are modified.

- They usually attend with support. 
- Students are included in my classrooms and accommodations such as guided notes hands on activities and additional time are made. I also provide a Down Syndrome student with personalized worksheets or tasks.

- $\quad$ Peer Tutoring takes place.

- Currently the students with special needs are in the classes and receive the same instruction as other students but they have special ed teachers with them assisting with notes and lab activities

- Most of the students I teach just have learning disabilities in reading so some things I do is read things for them or give longer time on tests. One boy can't talk or write so he has a lady help him. So, I adjust things for his understanding as well.

- I have students ranging from mild learning disabilities to those who are severely mentally or physically disabled. I work with our fantastic school special education teachers to create accommodations that allow them to have success based on their skill level.

- They are put in groups that contain regular learners.

- $\quad$ Specialized hearing equipment, visual aides, guided notes.

- They do all the same things my other students do with adaptation.

- Mainstreamed as much as possible accommodations in note taking, tests, assignments and labs. Have a blind students would like more info on how to accommodate him better.

- I currently have a few students w/ special needs that require a few accommodations. But they are simple things (like extra test time or printing notes). They are definitely contributing members of class and I enjoy them.

- I have a Para educator who helps me with two students I have and they are a big help.

- I treat them just like every other student, I try to give them extra help if they are extreme.

- I have several students in each class with special needs. I have tried to teach in a variety of different ways so that each student has the opportunity to learn. I have even modified certain assignments to meet the special needs of each student.

- I don't treat them all that differently than others - just grades are modified to pass fail. 
- I have had students with all the disabilities mentioned. I have worked closely with special education, psychologist counselors, tutors and others.

- I have about $30 \%$ of my students who have special needs or some type of need and I have tried to include them in all I do by slightly altering my activities and grading.

- I treat them just like the other kids until special situations develop.

- When unaware of some of the special needs they are treated fairly and often excel above expectations.

- I have students help those with special needs. Sometimes during labs they go back to their classroom.

- I include life skills students in my floriculture class and modify the curriculum somewhat. I have learning disability students on every class and do not change the curriculum other then providing their accommodations.

- I have a lot of students, but I don't feel I have the abilities to teach them or work with them.

- We are able to include most students as if they are not any different from other students. We do have some students that will help take notes and help tutor some of the students.

- For 16 years I have had all types special needs children mobility they are there with a peer tutor.

- I work hard to integrate all students into the program. I deal w/ students w/ seizure disorders.

- I change my level of expectations. Not necessarily lower, simply modified.

- I pick 3-4 students to work with the student. They are well equipped students and like doing it. This works well in a laboratory or even on written assignments.

- I have taught many students with hearing impairment and a large amount with IEP's. Most of the IEP's are learning disabilities of some kind.

- I have had several special needs students in my classes. 
- I don't have any special needs students currently. I do have several IEP students but have never been included in an IEP meeting.

- They are expected to complete the same assignments as all students. My expectations are not lowered for them. Currently, I have no help in class with IEP students. One year teaching "Earth Science" I did have a sped. Ed. Teacher in class everyday.

- I get ALL the special needs students in my biology classes. I am way overloaded with these students proportioned to "normal" students.

- If they can function safely and pass the safety test they can be in the shop.

- I make accommodations as needed or listed in IEP or 504. 30 or 216 students have an IEP most don't need anything out of the ordinary.

- It is very difficult to describe. In my class I try to include every student. They are felt wanted and a part of the class. They work with the other students so they feel they are no different than their peers. They are giving extra time on assignments and given assignments that challenge them, but not cause them to feel overwhelmed and inferior.

- I changed the assignments to fit the student.

- I make accommodations based on their needs on an individual basis, but they are treated the same. They are graded based on their ability, but expected to try to reach new levels of learning. I work closely with the Special Ed teachers to help the students be successful in my program.

- I have a few in class - I work w/ special ed teacher for how much to require of them. Group work works ok.

- I have students that cannot see out one eye. I put him on the front row.

- I try to ask the students and teachers what to do. I prepare and present items to aid/teacher in advance to help me make modifications.

- I do currently have special education students and depending on the disability they are involved.

- They are part of the class and are expected to participate like anyone else though there is usually an aid in the class to help them.

- Guided notes learning partners. 
- None.

- My special needs students take up most of the seats in my one floriculture sections. They do the same things as everyone else.

- I have very severe students to mild. I do my best to provide them a great experience.

- Class size is usually decreased, students put into classes with low achievers.

- Safety is \#1 if ok they are just one of the class members.

- I have had all "types" of students in my class. At one time I had a complete hearing impaired student for four years. He graduated three years ago and is working as a welder. I currently have students with mild-severe mental difficulties, behavior disorders, and intellectual disabilities. And 504's. I try my best to buddy them up, overtly include, attend IEP's, print lessons out and directly instruct these students.

- Regular classroom activities, daily learning.

- I spend time making sure work is complete.

\section{What education/professional development regarding inclusion have you received?}

Verbatim comments (spelling and grammar errors included)

- 1 College Class SPED 4000

- None

- College Classes - Taught one year in an enclosed class (not ag.) w/ an aide learned skills there.

- College courses my wife is a special education teacher

- ESL Training

- Not much

- Mostly in college and some from my school SPED

- College Courses

- None 
- Working with special needs classes in college

- SPED Class at USU

- Just a few classes in college and some work with special needs students at home.

- Little to none

- $\quad$ 2-3 courses including some in ELL

- College Course work SPED 4000

- College Courses - In-school training

- The general special ed classes at the university

- Just what I had in college

- 3-4 workshops through district, ACTE, and NAAE. I have spent one-on-one time with our special ed. Dept.

- None

- Accommodations seminar in Park City, one college course.

- On the job training Experience

- $\quad$ Sped course required for BS

- SPED Classes USU some instructions from the SPED teachers at my schools

- None other than classroom management SPED 4000

- None

- Just a special Ed course in college

- In school pro. Dev class, member of special education committee

- One class in college sped 4000

- Words, speeches, nothing meaty. 
- None

- I worked for a couple of years with special needs students at Cross

- Only the special education course @ USU

- Just what we got at USU not a lot

- 1 college class that briefly included some information on inclusion.

- None

- I received education at an elementary teacher level working with mentally and physically impaired students at UVSC.

- I have taken several reading classes and there have been many in-service opportunities. (hearing, speech, ADD etc.)

- Some classes in college and a few seminars especially for dealing with students with IEP's and deaf students.

- College, and some district workshops

- None

- None

- Series of classes on working with autistic students put on by my district

- ESL training, special education training, behavioral modified classes, state law "rights" training pertaining to including special education students in classes.

- $\quad$ Very little

- Masters in Diverse Learning from U of P

- Not much, one class in college and discussions with my special education instructor.

- Special education teachers have done workshops. My BYU classes included work w/ special education. 
- Just what classes we have taken at college I think that they just expect us to know how to do it. I had a lot of good help from my mother who was a special education teacher

- I teach the students special education puts in my class. I have had 1 class when going to school.

- Special education at USU

- Regarding inclusion - not much

- Not a whole lot!

- The usual except I took special education as a summer distance course and got very little from it.

- None

- Very little

- Just a couple of workshops 14 years ago!

- None

- District In-service

- $\quad$ Some at the high school - short courses

- I had one courses in college. I have taken a Sign Language class. Our district has had one in-service about disabled students.

- Educational courses in Ag. Degree

- None

- College Class? 


\section{What support services are currently available to you?}

Verbatim comments (spelling and grammar errors included)

- Aids-support staff

- $\quad$ Special Ed Teacher

- Aides, Technical Equip. if needed, IEP Mtgs. In hallways, calls to parents.

- $\quad$ Special Ed Teacher

- Special Ed. Dept.

- Peer tutor, Para-educator

- SPED in my school.

- $\quad$ Special Ed. Teachers

- None

- A full range from the 9 high school that Ii teach for

- Very little the SPED at our school doesn't do a very good job in making us aware of the accommodations we need to make.

- I have a Para educator that works with all the CTE classes and also a great special needs dept. at the school

- I ask questions to resource teachers

- Paraprofessionals, workshops and district support.

- Special education teachers and peer tutors that generally are not a lot of help.

- $\quad$ Special Ed. Teacher District Psych

- Special education teachers

- My school has a lot of special education teachers that are willing to help in any way. They have been extremely helpful.

- School, special ed. Dept., counselors, psychologist etc. 
- $\quad$ Special Ed. Teacher

- $\quad$ Special ed. dept. teachers - sometimes

- $\quad$ Special Ed. Teachers

- SPED/Aide

- I have great SPED teachers at my schools! They are helpful and willing to answer my?'s

- Special Ed Teacher and Councilor IPE Team

- Special Ed Teachers

- I meet with the special education teacher 2 to 3 times a week to discuss modification to lessons to help my students with special needs.

- $\quad$ Sped teachers in my school are great!

- All those listed above

- I have a special education department but no help!

- Zip, zero, and prefer this method.

- Special education teachers

- All the special needs teachers offer support and help at our school

- Special Education Teachers

- None I know of Special Ed teachers expect you to know already

- We have a TA that is in each class that helps students with disabilities. They are able to use other TA to help with things such as reading tests and other accommodations. We have "signing" TA for our deaf students.

- Peer tutors, etc.

- Very cooperative sped dept. 
- IEP, Counselors in my school.

- $\quad$ The Resource Department - extremely helpful for test taking or achieving accommodations.

- The special education department works very closely with my school and includes us in all IEP meetings.

- Paraprofessional aide for student

- $\quad$ Peer tutors, Special Ed Aides

- There are several students who go to class with special needs students to help them in class but I have never had one in my class.

- Special Ed. gives me a list of IEP and 504 students at the beginning of the school year. Occasionally, I am involved in the IEP meeting. That's it.

- Our SPED team is great to work with. Our life skills teacher always consults with me before putting her students in classes where special accommodations are needed.

- Counselors, special ed teachers, paraprofessionals

- Special Ed teachers

- All I need

- Special education teachers, paraprofessionals, Professional Development classes.

- Special ed. Teachers.

- The special education teacher. She is only here for $1 / 2$ the day.

- Special Ed teacher

- None

- Paraprofessionals, special education teacher

- Not much I have had a team taught class in the past and it was awesome. Now we are told to grade them pass fail and pass them to stay on the safe side, or give them a letter 
grade if they are passing, but if they fail just give them a pass to safe. ? weird eh

- Very few!!

- ?

- None

- $\quad$ Sp Ed dept. resources dept.

- $\quad$ The special education dept.

- Teachers Aides

- Teachers Aides etc

- Not really sure - I have not asked

- I get a list of SPED students; I don't know what their disabilities are.... In one class, there is an AID, but she just sits in the class and takes notes. I attend about one IEP a month, and usually the SPED people tell us to "make grade accommodations" if the students are trying, and allow "extra time" for the SPED students to turn in work.

- Special education teachers, audio aids in classroom aids

- Class aids

- Administration, sp. Ed. Teachers, parents 